
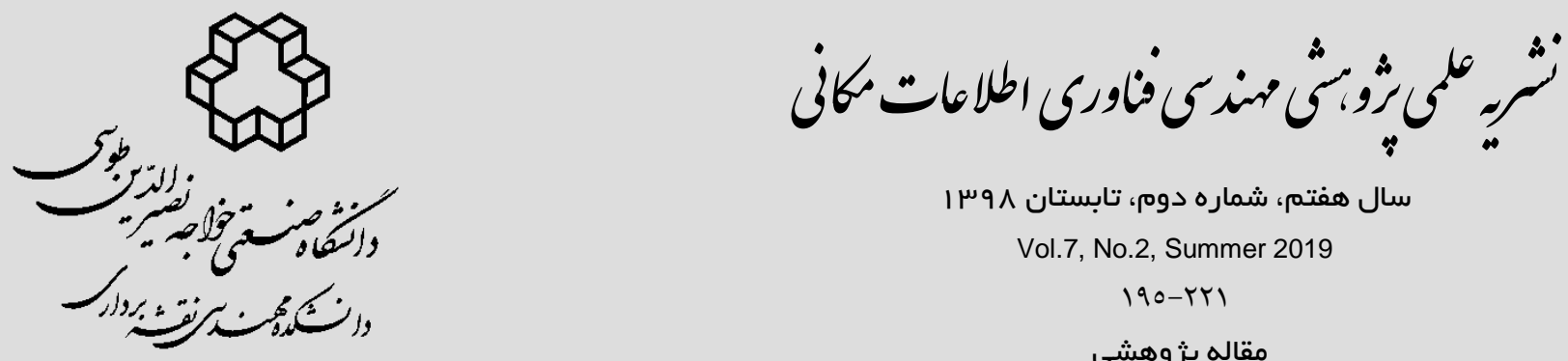

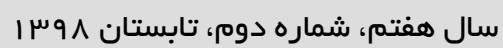
Vol.7, No.2, Summer 2019

190-rY1

مقاله يزّوهشى

شبيهسازى عاملمبناى تخليه اضطرارى شهر ها در هنگَام حملات تروريستى

صفا خزائى'

1- (ع) دانشيار دانشكاه جامع امام حسين

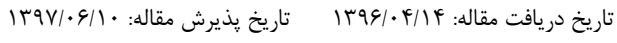

جُكيده

در سـاليان اخير، مديريت صـحيح منابع و زمانبندى مناسـب جهت تخليه اضطرارى شهروندان از محل حوادث تروريستى بهطور گسترده مورد

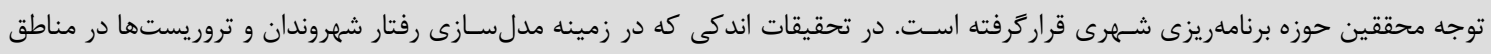

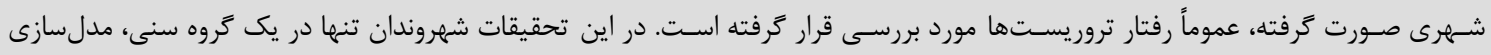

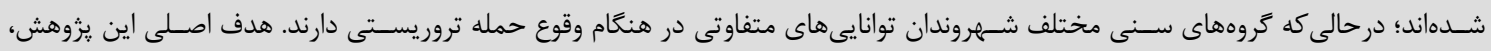

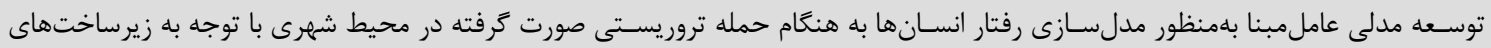

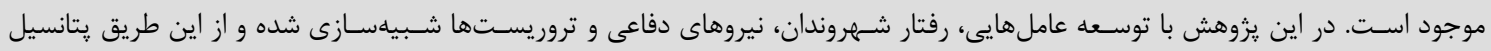

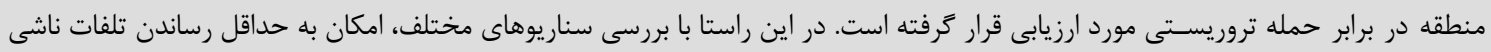

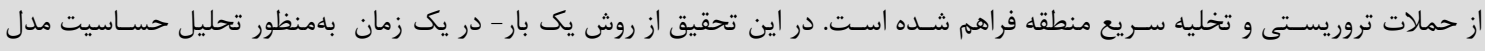

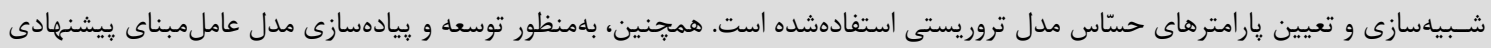

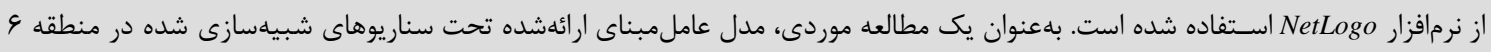

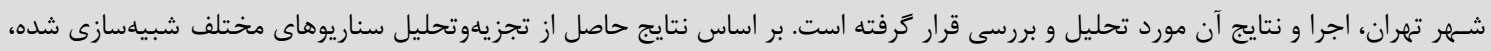

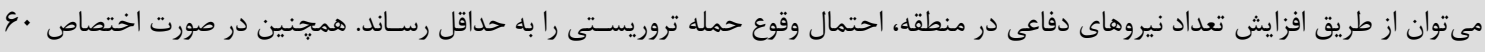

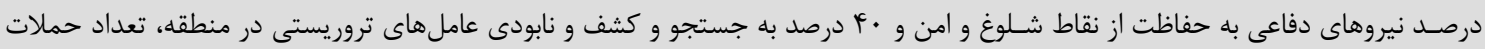

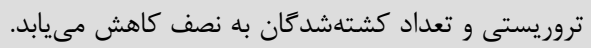

كليدوازهها: شبيهسازى عاملمبنا، تخليه اضطرارى، حمله تروريستى، تحليل حساسيّت.

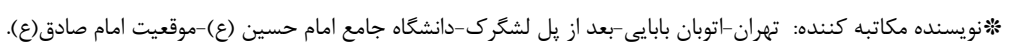
تلفن: • 
ارتباط با ساير عاملها و محيط مبادله مىنمايند،

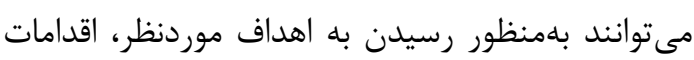
لازم را انجام داده و تصميمَّيرى نمايند [ب]. شبيهسازى حمله تروريستى بهعنوان يديدهاى غيرقابل

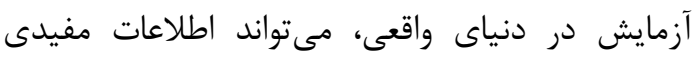

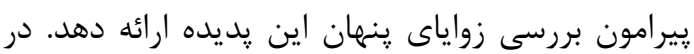

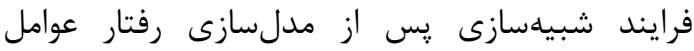

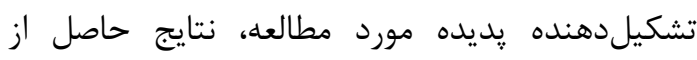

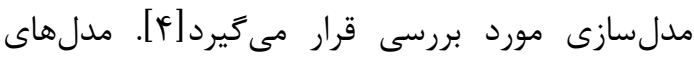

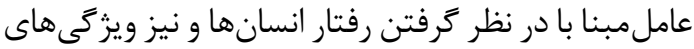
محيط، يكى از موفقترين روشها بهمنظور مدلسازى

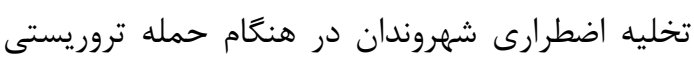
ي يشنهاد مىشود. يك عامل، مى تواند نمايندهاى از طرف

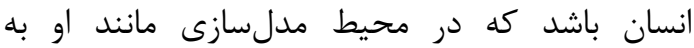
تصميمَيرى و انجام كارهاى مختلف مى يردازد. محيط بهعنوان فضايى كه عامل ها در آن حركت و فعاليت نمارئ نموده و با يكديخر به تبادل اطلاعات مىيردازند، تعريف

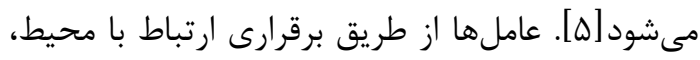
محيط را حس نموده و بر اساس تغييرات به وجود آهده در محيط بلمنظور رسيدن به هدف تعيينشده تلاش

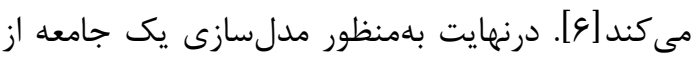

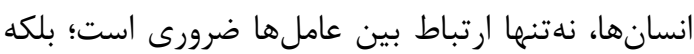
عامل ها بايد بتوانند با يكديخر هماهنخ بوده، همكارى و

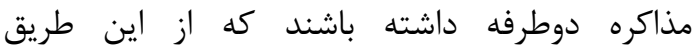

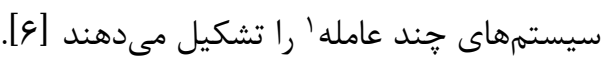

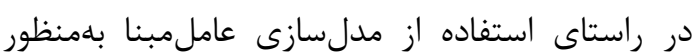
شبيهسازى رفتار انسانها، با استفاده از مفاهيم عاملها،

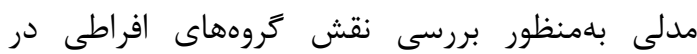

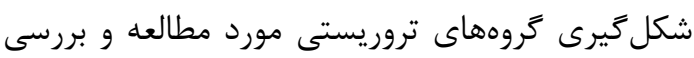

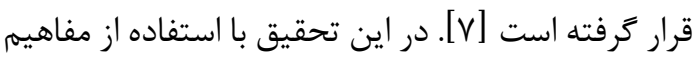
شبكه اجتماعى (كه شبكه ايجادشده بين افراد جامعه در

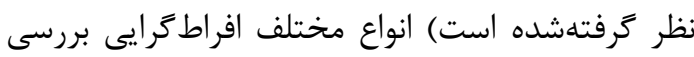

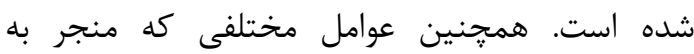
افراطكرايى ׳مىشوند، (مانند كسانى كه با ايدئولوزىهاى
- 1- - 1قدمه

حملات تروريستى از اساسىترين معضلات جامعه جهانى و خطرناكترين تهديدها بر ضد حقوق ملتها و ثبات

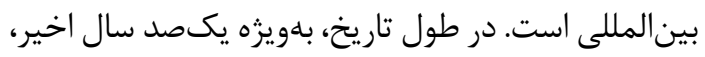
تروريسم، ريشه مهمترين تهديدها بر ضد صلح و امنيت جهانى بوده است. در سالهاى اخير با توجه به حوادث

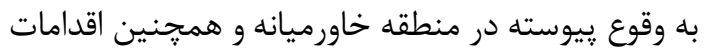
تروريستى، آمادگى مقابله در برابر اين رفتارها در كشور، بهنوان يكى از مسائل مهم امنيتى مطرح است. يكى از اصلىترين اقدامها يٍ از وقوع حملات تروريستى، تخليه

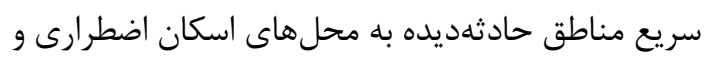
ايمن تعبيهشده در شهر و يا خارج از شهر در كمترين

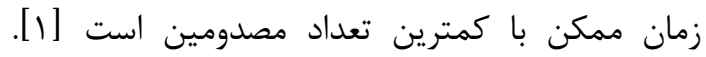

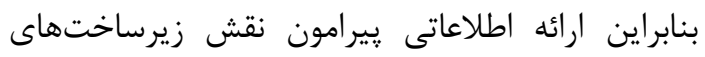

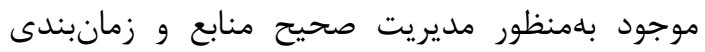
مناسب در خروج شهروندان از محل حادثه قبل از آسيبديدن و جانباختن، براى مديران و برنامهريزان بسيار اهميت دارد. از طرفى رفتار افراد و تأثيرات عوامل ئر برن محيطى در فضاى شهرى باعث شده تا موضوع تخليه

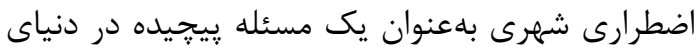

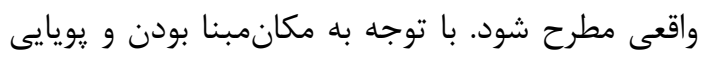
اين رفتارها مىتوان به كمك تركيب مدل هاى عامل مبنا و سيستم اطلاعات مكانى آنها را شبيهسازى نمود.

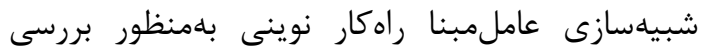

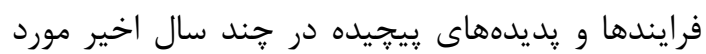
توجه قراركرفته است. در اين راهكار با در نظر كرفتن

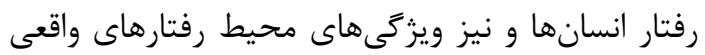

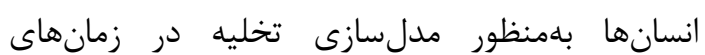

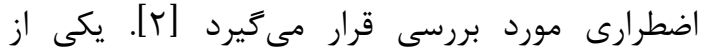

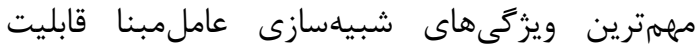

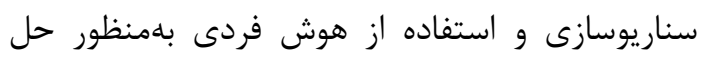
مشكلات يِيجيده در دنياى واقعى است. در اين رويكرد

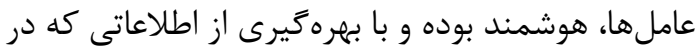

${ }^{1}$ Multi Agent Systems 
حملات تروريستى از كروههاى افراطى دينى مورد

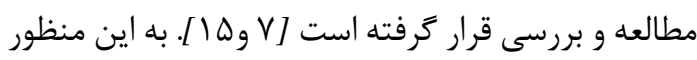
عاملهايى توسعه داده شد كه با استفاده از مفاهيم آناليز

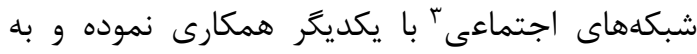

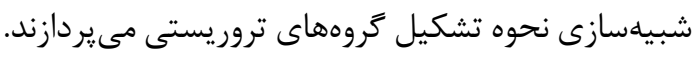

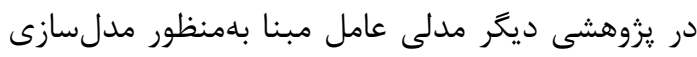

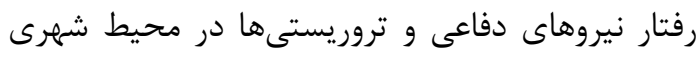

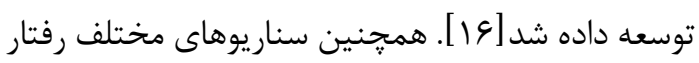

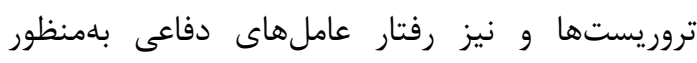

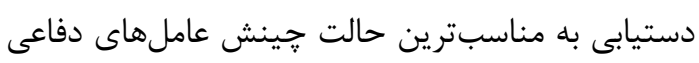

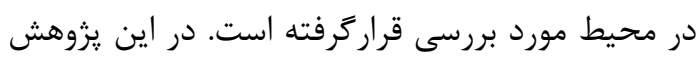

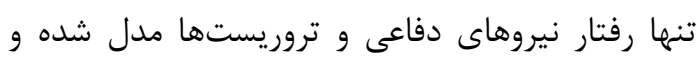

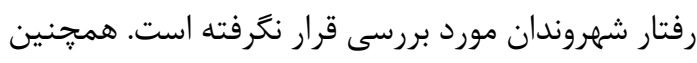

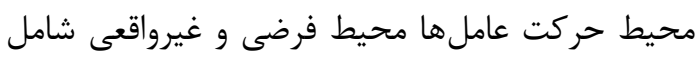
يكى يا جند منبع (كه عامل هاى دفاعى سعى دانى در محافظت

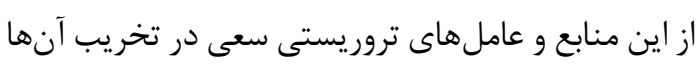

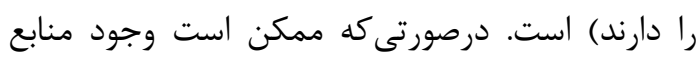

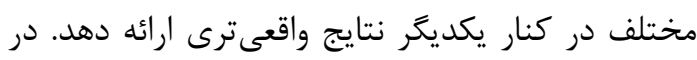

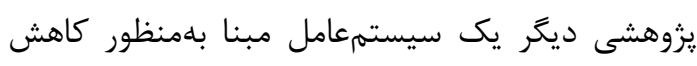

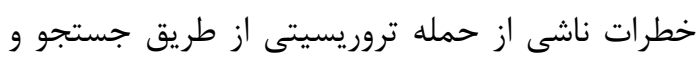

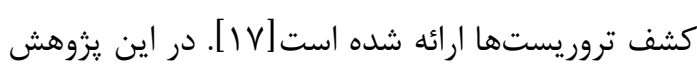

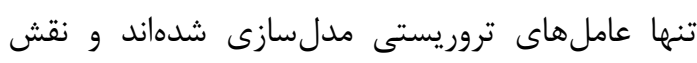
عامل هاى دفاعى و عامل هاى شهروند مورد بررسى قرى قرار

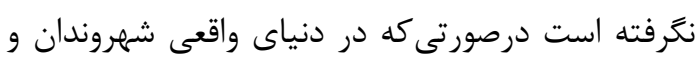

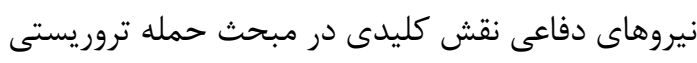

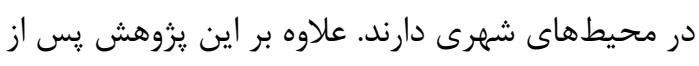

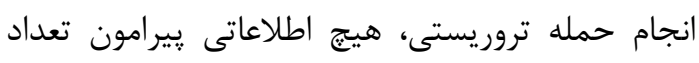

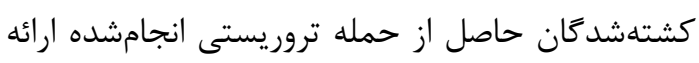

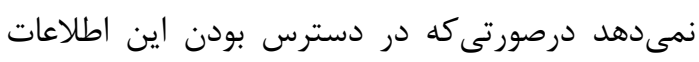

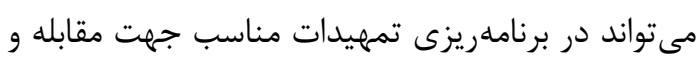
كاهش خسارات ناشى از حمله تروريستى بسيار مفيد ترنيد

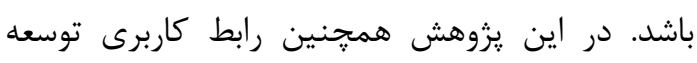

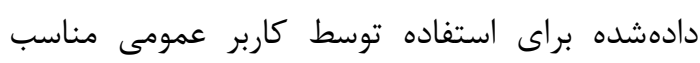

${ }^{3}$ Social Network Analysis
دينى و يا خشونتآميز مذهبى يا سياسى به تشويق

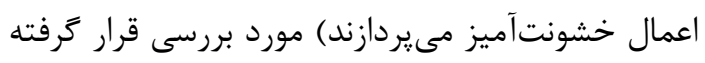

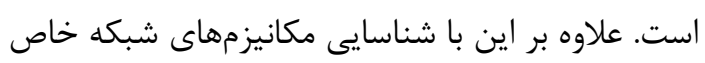

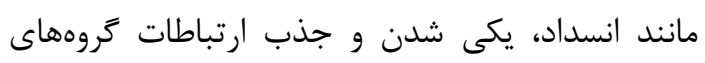

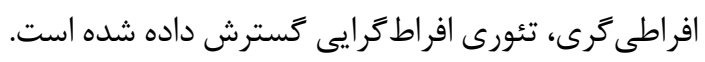

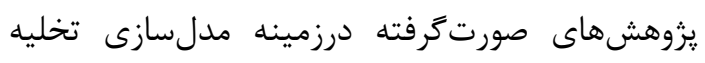

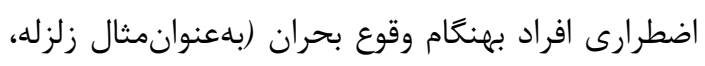
آتشسوزى، حمله تروريستى) عموماً به دورانه دودسته

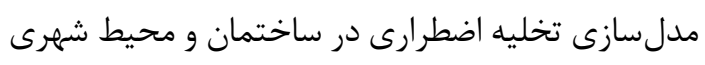

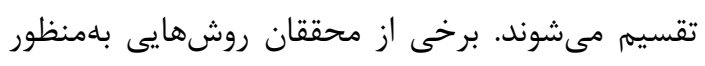

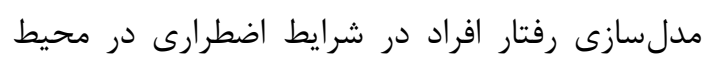

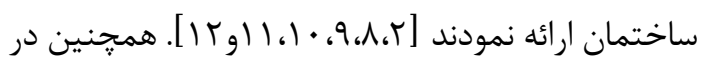

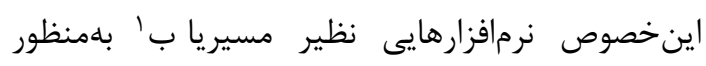

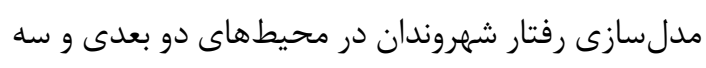

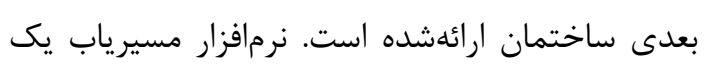

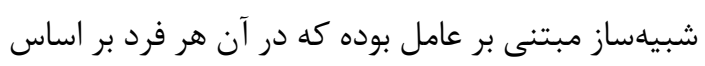

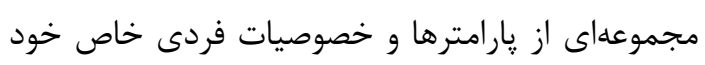

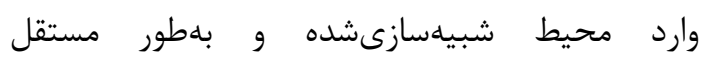

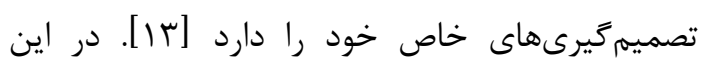

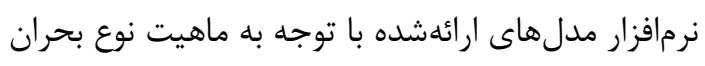

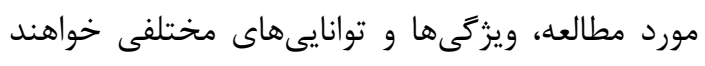

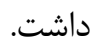

يزوهشهاى كمى نيز در زمينه مدلسازى حملات

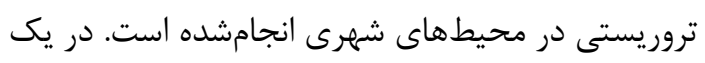

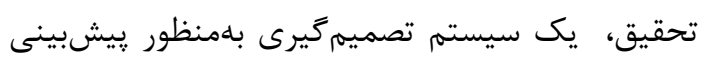

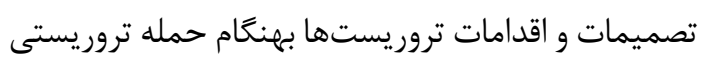

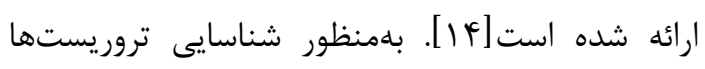

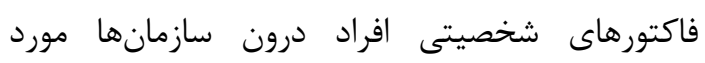

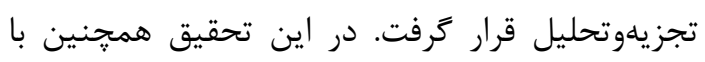

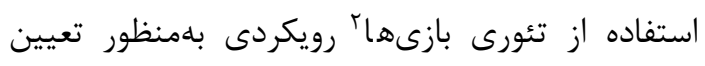

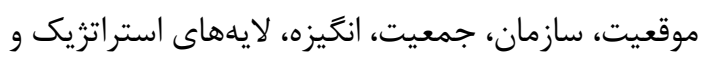

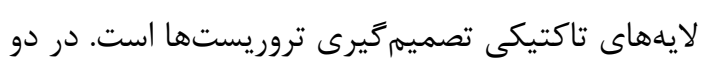
يروهش با ارائه مدلى عامل مبنا، نحوه شكل تصديرى ترويست

${ }^{1}$ Pathfinder

${ }^{2}$ Game Theory 
انرزى براى عاملهاى شهروندان بهصورت تابعى از زمان

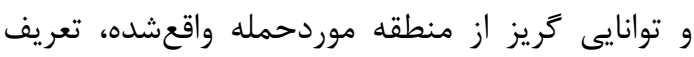
مىشود. علاوه بر اين، ازآنجايىكه با توجه به مطالعات مونات

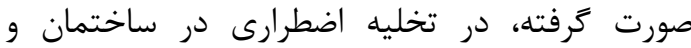

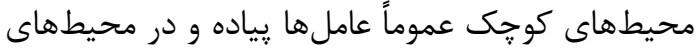
شهرى عامل هاى سواره در نظر كرفتهشدهاند؛ لذا در اين

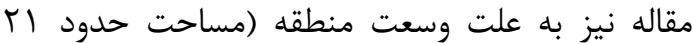
كيلومترمربع) عامل ها سواره فرض شدهاند.

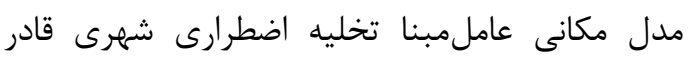
خواهد بود كه با بررسى رفتار تروريستها و شهروندان بهنكام وقوع حمله تروريستى در منطقه شهرى و از طريق بررسى سناريوهاى مختلف، اطلاعات مفيدى ييرامون تلفات ناشى از وقوع حمله تروريستى ارائه دهد.

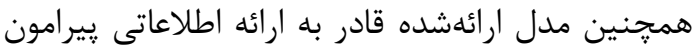
موقعيتها و نقشه محل وقوع حمله تروريستى و وانهان اطلاعاتى پيرامون تعداد كشتهشدكان در هر حمله تروريستى صورت گرفته است. اين موضوع به مديران و كارشناسان كمك مى كند تا بهمنظور به به حداقل ميزان كشتهشدكان تصميمهاى مناسب را اخذ نمايند و از اين طريق باعث افزايش قدرت تصميمگيرى و

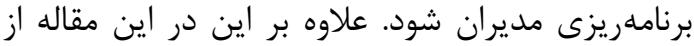

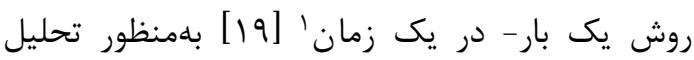
حساسيتَ مدل شبيهسازى عامل مبناى حمله تروريستى استفادهده است. به دليل تعداد بالاى يارامترهاى ورودى مدل شبيهسازى ارائهشده، ابتدا يارامترهاى شبيه به يكديكر دستابندىشده و سِّيس حساسيت دسته يارامترها بهمنظور شناسايى دسته بارئه

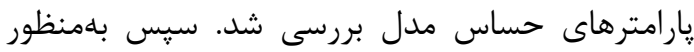

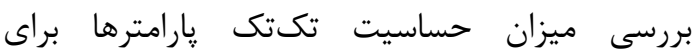
بارامترهايى كه حساسيت بيشترى دارند، روش تحليل حساسيت يك بار-در-يك زمان استفاده شد.

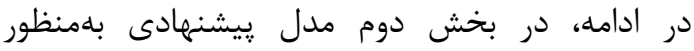
مدلسازى و شبيهسازى تخليه اضطرارى شهروندان در هنگام حمله تروريستى ارائه مىشود. بخش سوم به لهاريا

${ }^{2}$ Sensitivity Analysis
نيستند و تنها نتايج مدلسازى نمايش دادهشده است؛ درصورتى كه در مديريت بحران تغيير مقادير مختلف ناديان

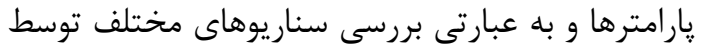
مديران و كارشناسان اهميت دارد. در يك تحقيق نيز باريا

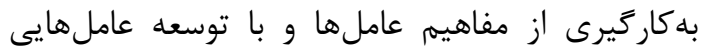

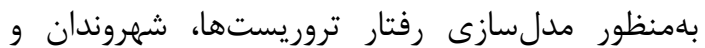

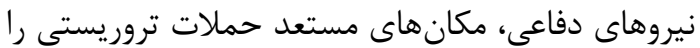

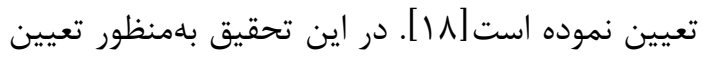
محيط اجراى عاملها سادهسازى زيادى انجامشده است. درصورتى كه بهمنظور نزديك بودن مدل ارائهشده به دنياى واقعى مىبايست با حفظ اصل جكيدگى، مدل

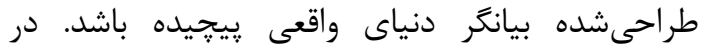

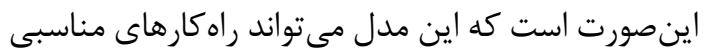
را بهمنظور ييادهسازى در دنياى واقعى ارائه دهد. علاوهبر اين در اين تحقيق بهمنظور مدلسازى رفتار شهروندان تنها يك كروه سنى توسعه دادهشده است. درحالى كه به كروههاى سنى مختلف شهروندان توانيىهاى متفاوتى

بهنخام وقوع شرايط بحرانى حمله تروريستى دارند.

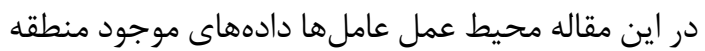
9 شهر تهران شامل شبكه معابر شهرى، مناطق امن

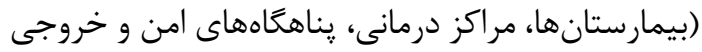

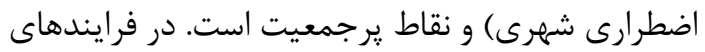

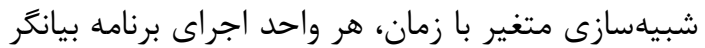
تابعى از زمان در دنياى واقعى است. در اين مقاله باتوجه

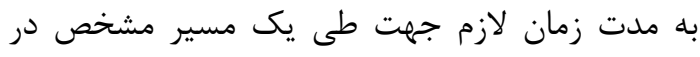

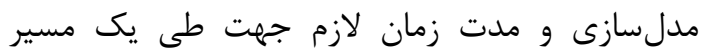
مشخص در دنياى واقعى توسط يك عامل، هر واحد لآمد اجراى برنامه معادل يك دقيقه در نظر كرفته شد. تابع انرزى تعريفشده براى عاملهاى تروريست بلهصورت

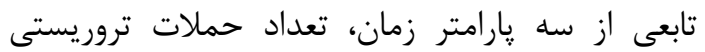
انجامشده توسط عامل تروريست و تعداد روابط اين عامل با ساير عاملهاى تروريست تعريف مى گردد. دو عامل تروريست درصورتى كه در فاصله مشخصى از يكديخر قرار

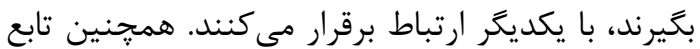

\section{${ }^{1}$ One-at-a-time}


عامل دفاعى باهدف كشف و نابود نمودن عامل هاى تروريست و دفاع از مكانهاى امن

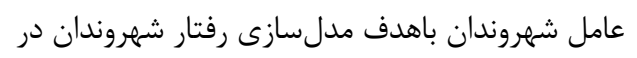

$$
\text { محيط شهرى }
$$

شكل ( ) نحوه تعامل ميان عامل ها را نمايش مى دهند.

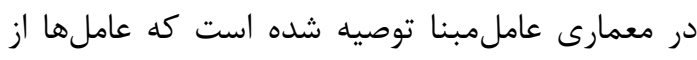

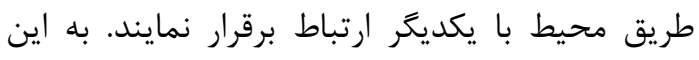

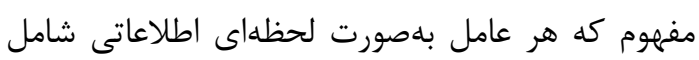

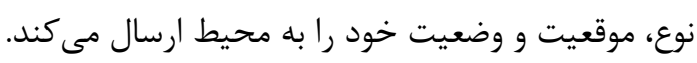

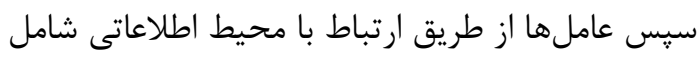

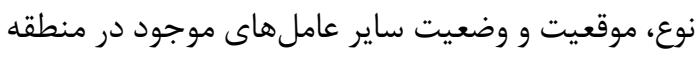

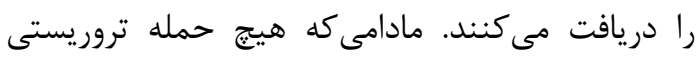

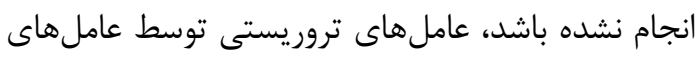

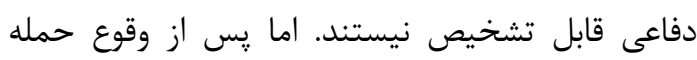

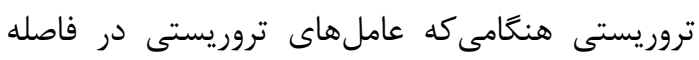

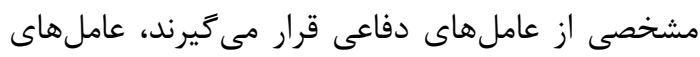

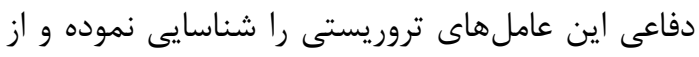

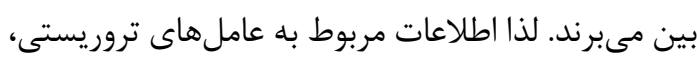

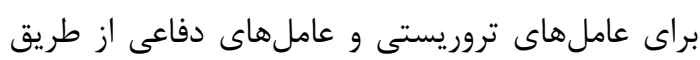

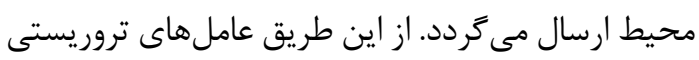
با يكديكر ارتباط برقرار مى كنند. باتوجه بـ به إنه ساختار

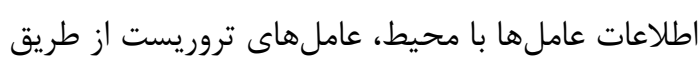

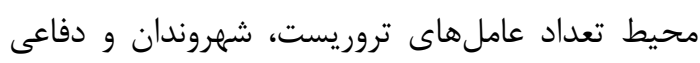

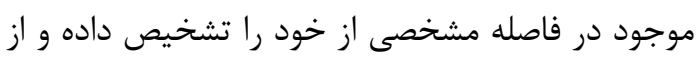

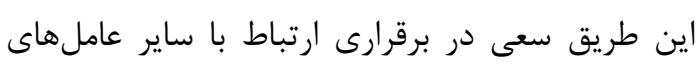

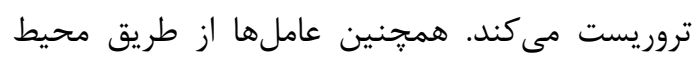

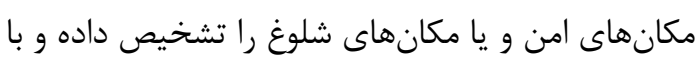

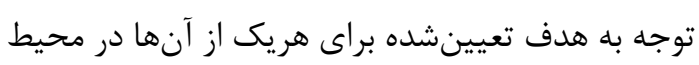

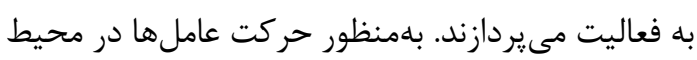

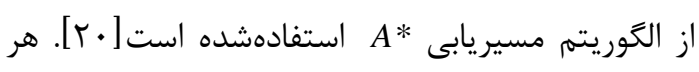
يك از عاملها درصورتى كه در حمله حضور داشته باشند

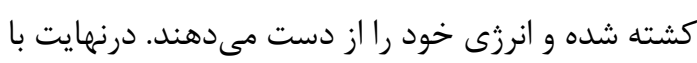

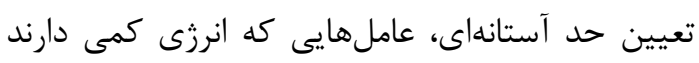

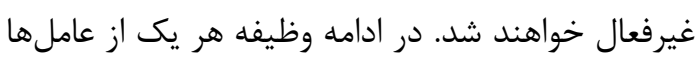

شبيهسازى و تحليل نتايج از طريق بررسى سناريوهاى مختلف شبيهسازى شده و تحليل حساسيت مى يردازد.

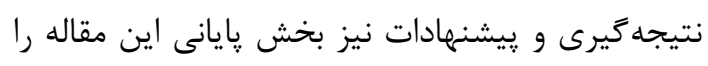
شكل داده است.

r- مدل مكانى عاملمبنا جهت اده تخليه اضطرارى شهروندان در اين تحقيق با توسعه مفاهيم ارائهشده در يزوهشهاي

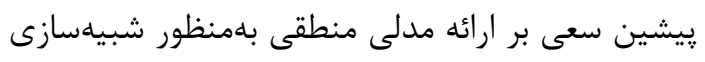

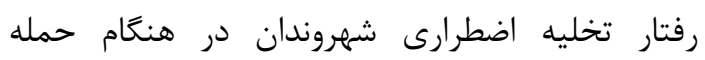

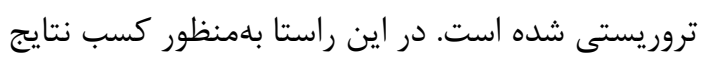

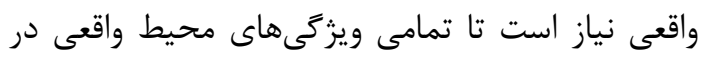

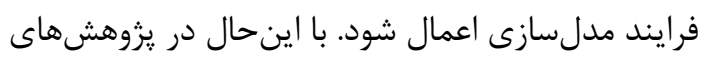

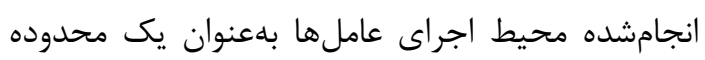
ساده (بدون در نظر گرفتن معابر شهر، بيمارستان ها و ...)

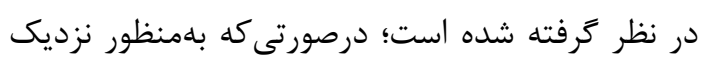

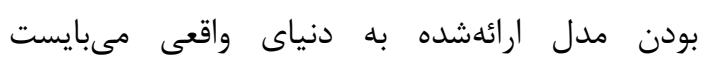
ويزگى هاى واقعى محيط در نظر كرفته شود. همجنين ارنين

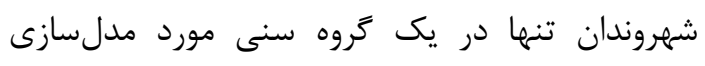

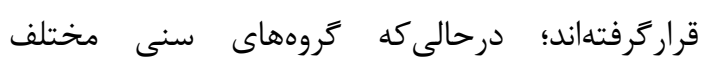

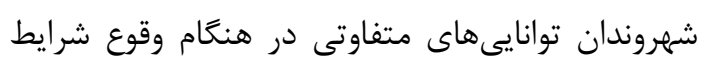
بحرانى حمله تروريستى داشته و بلهطور مستقيم در نتايج

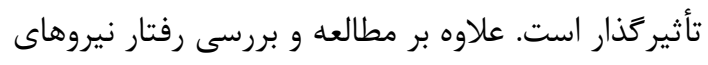

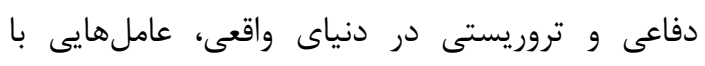
رويكردى متفاوت نسبت به كارهاى انجامشده توسعه دورئ

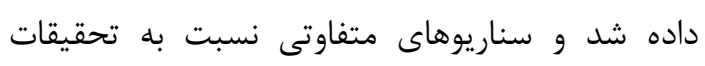

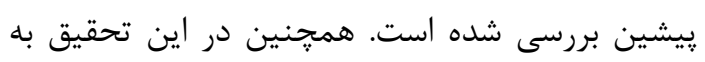

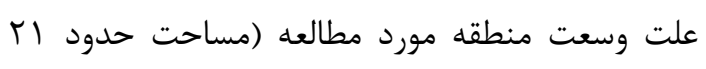
كيلومترمربع) عامل ها سواره فرض شدهان مرد مطاند.

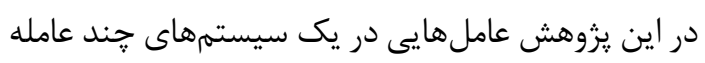

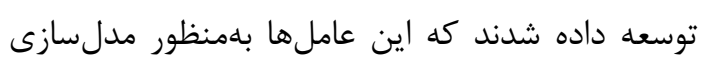

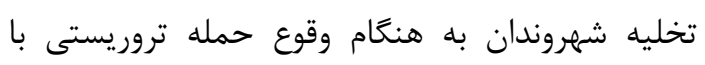
يكديكر همكارى مى كنند. در مدل ارائهشده سه دسته

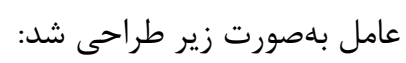
عامل تروريست باهدف انجام حمله تروريستى ناجن 
و نحوه عملكرد هركدام بهمنظور تشكيل مدل عامل مبناى تخليه اضطرارى شهرى تشريح خواهد شد.

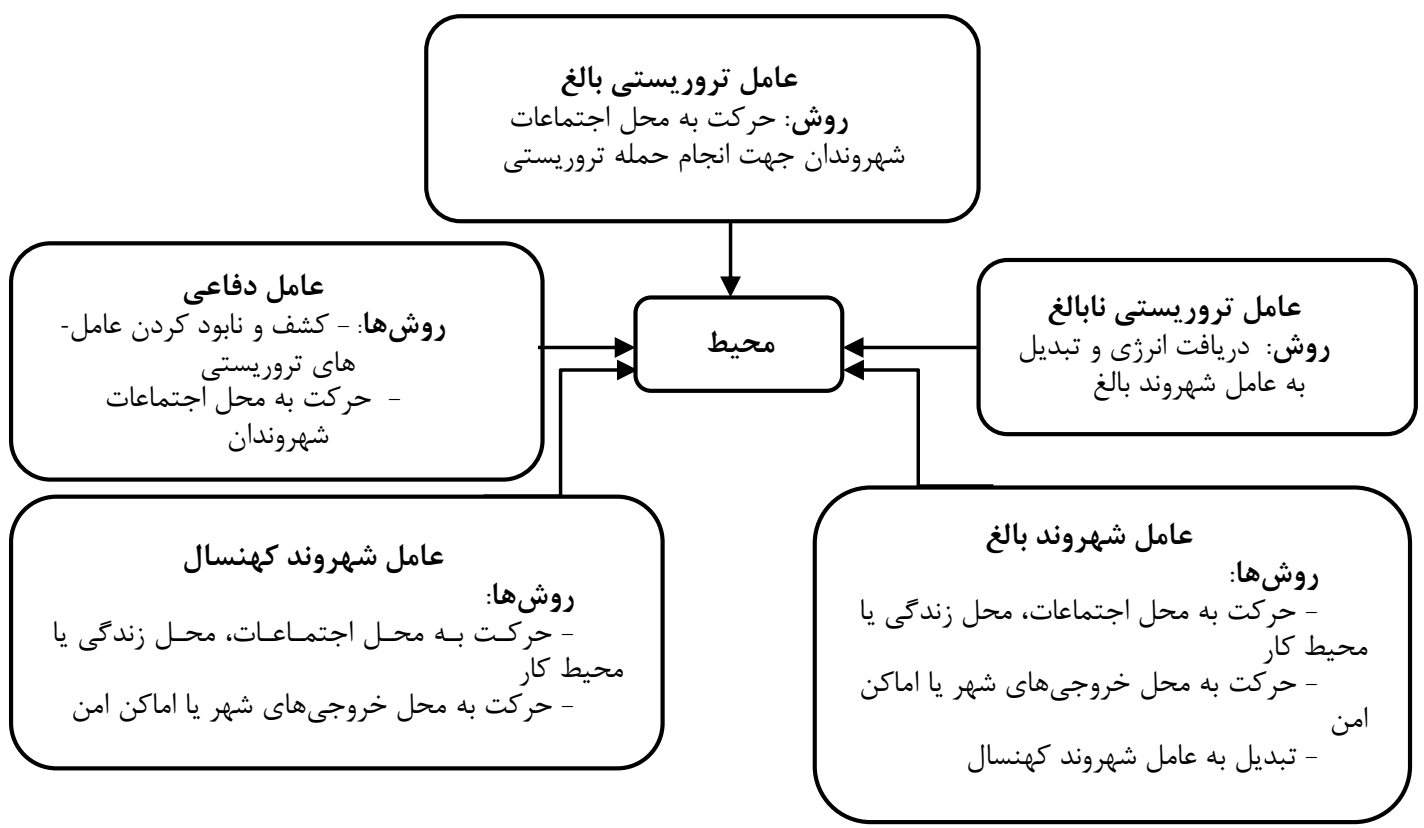

شكل ا: نحوه تعامل ميان عامل در مدل تخليه اضطرارى شهرى

شكل(T) جرخه حيات عامل تروريست را نمايش مى دهد. عامل تروريستى بالغ از طريق محيط محلهاى اجتماع

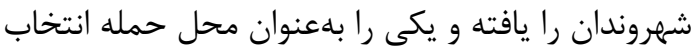
مىنمايد. بهمنظور بررسى امكان و يا عدم امكان شرايط لازم جهت انجام حمله تروريستى اين عامل در هر مكان

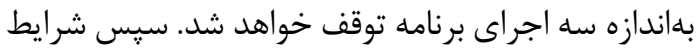
بهمنظور انجام حمله تروريستى را بررسى نموده و در دراس

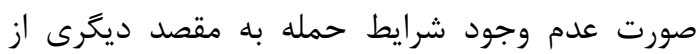
محيط حركت مى كند. اين عامل بهمنظور حركت به به

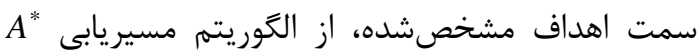

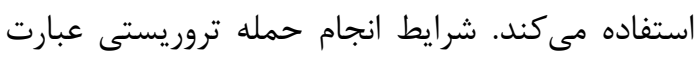

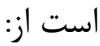
• ازآنجايىكه در دنياى واقعى براى انجام حمله تروريستى موفق حداقل جند تروريست بايكديكر همكارى مى كنند لذا حداقل n عامل تروريستى در فاصله مشخصى از محل قرار داشته باشند.

\section{r-1- عامل تروريست}

اين دسته از عاملها باهدف بروسى رفت رفتار تروريستها بامنظور انجام حمله تروريستى توسعه داده شداند. عاملهاى تروريست وظيفه انجام حملات تروريستى در

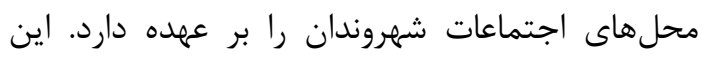
عاملها با دريافت مقدار مشخصى از انرزى مى انواعنداند حمله تروريستى انجام دهند. در دنياى واقعى براى انجام

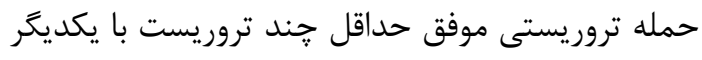
همكارى مىكنند كه بهمنظور يشتيبانى از يكديكر بامنظور رسيدن به هدف تروريستى خود مىبايست تاحدودى به يكديخر نزديك باشند. عاملهاى تروريست بلوسيله ارتباط با ساير عامل هاى تروريست، درك بالايكي ترديك در مورد محيط اطراف به دست خواهند آورد. اين درك دائ داك بالا به عاملهاى تروريست كمك مي كند تا بتوانند به

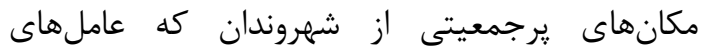
تروريست بيشترى نيز حضور دارند حركت نموده و از اين طريق به حمله تروريستى بيردازند. 


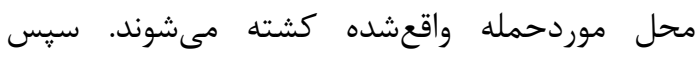

e عاملهاى موجود داراى حداقل مقدار انرزى e

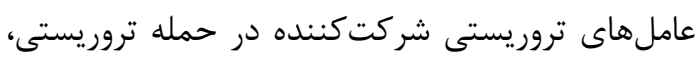
بر اساس نوع و مقدار انرزى عاملهاى شهروندى كه از • حداقل تعداد x عامل شهروند در شعاع مشخصى

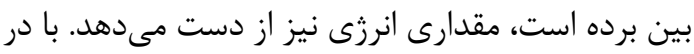
حضورداشته باشند.

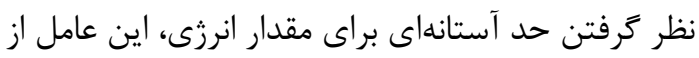
بين مىرود. تعداد عاملهاى دفاعى موجود در محل بيشتر از بـ نباشد. در صورت انجام حمله تروريستى، با توجه به انرزى عاملهاى تروريست، تعدادى از عاملهاى موجود در

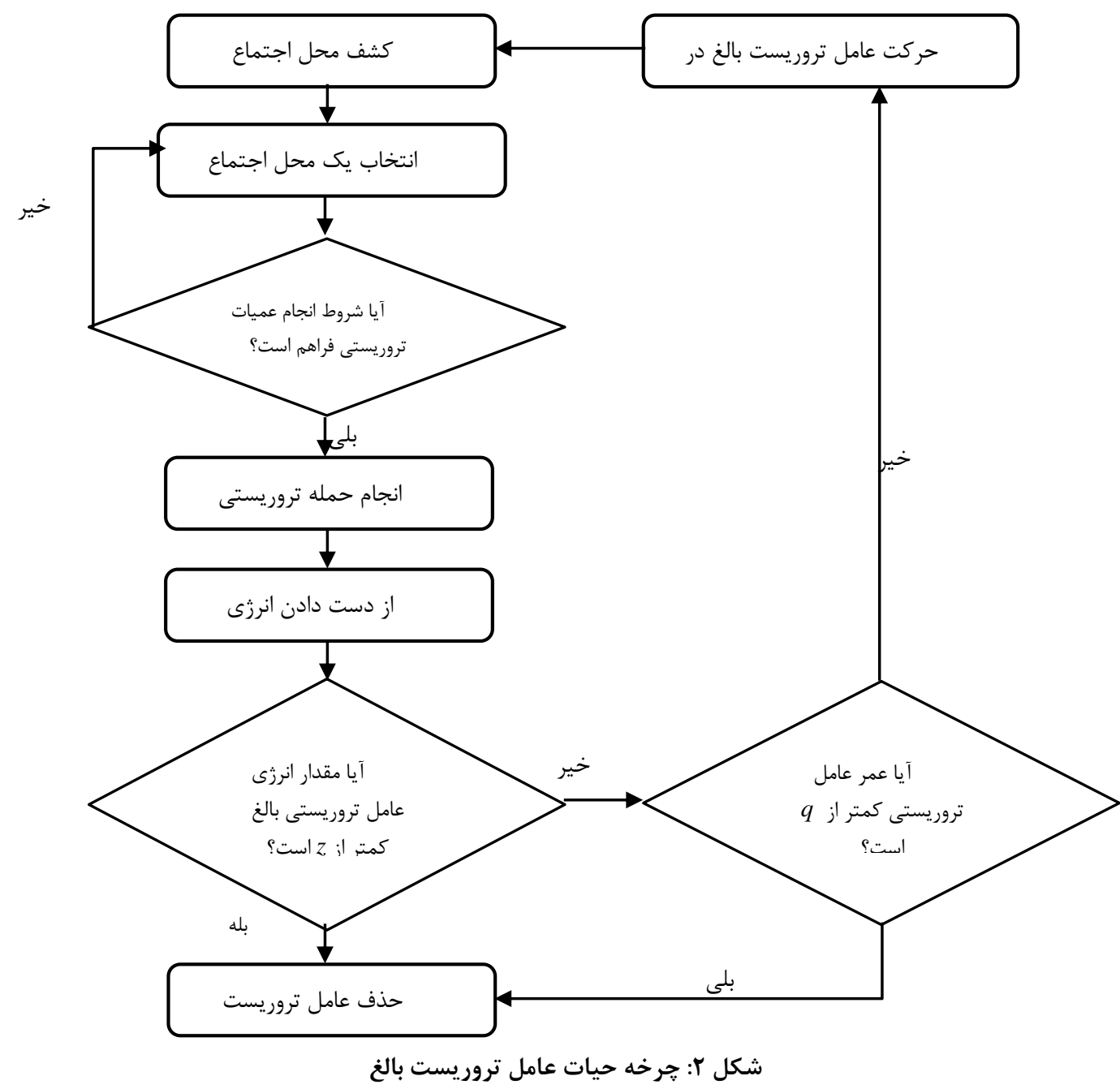


استتار شده و از ديد شهروندان و عاملهاى دفاعى مخفى

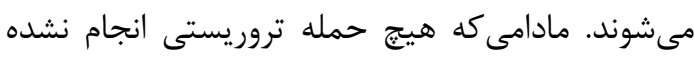
باشد، عاملهاى تروريستى توسط عاملهاى دفاعى قابل

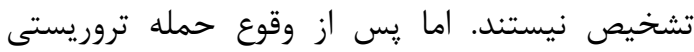
هنخامى كه عاملهاى تروريستى در فاصله مشخصى از

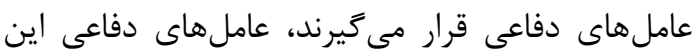
عامل هاى تروريستى را شناسايى نموده و از بين مىبرند. در غيراينصورت و در خارج اين فاصله عاملهاى

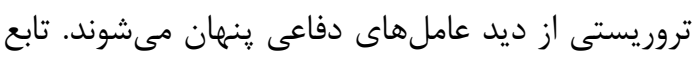
انرزى براى اين عامل بلصورت تابعى از زمان تعريف

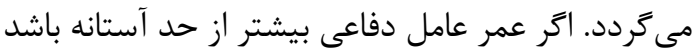
اين عامل از بين مىرود.

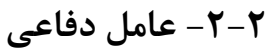

هدف عاملهاى دفاعى بررسى رفتار نيروهاى دفاعى دفاعى إمائ بلمنظور محافظت از شهروندان، مكانهاى امن و نيز كشف و نابود نمودن عامل هاى تروريست است. شكل (بان آنائ جرخه حيات عامل دفاعى را نمايش مى دهد. ازآنجايى كه ترنه احتمال وقوع حملات تروريستى در محل اجتماعات

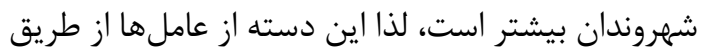

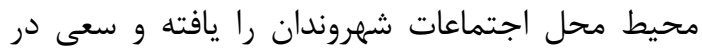

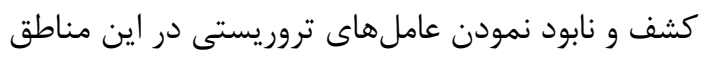

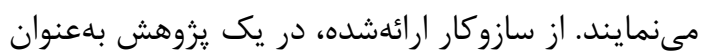
روش يايه بهمنظور تشخيص عاملهاى تروريستى توسط

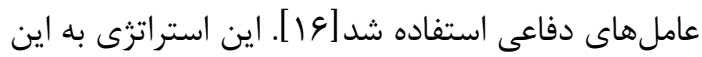
صورت است كه عاملهاى تروريستى در ميان شهروندان

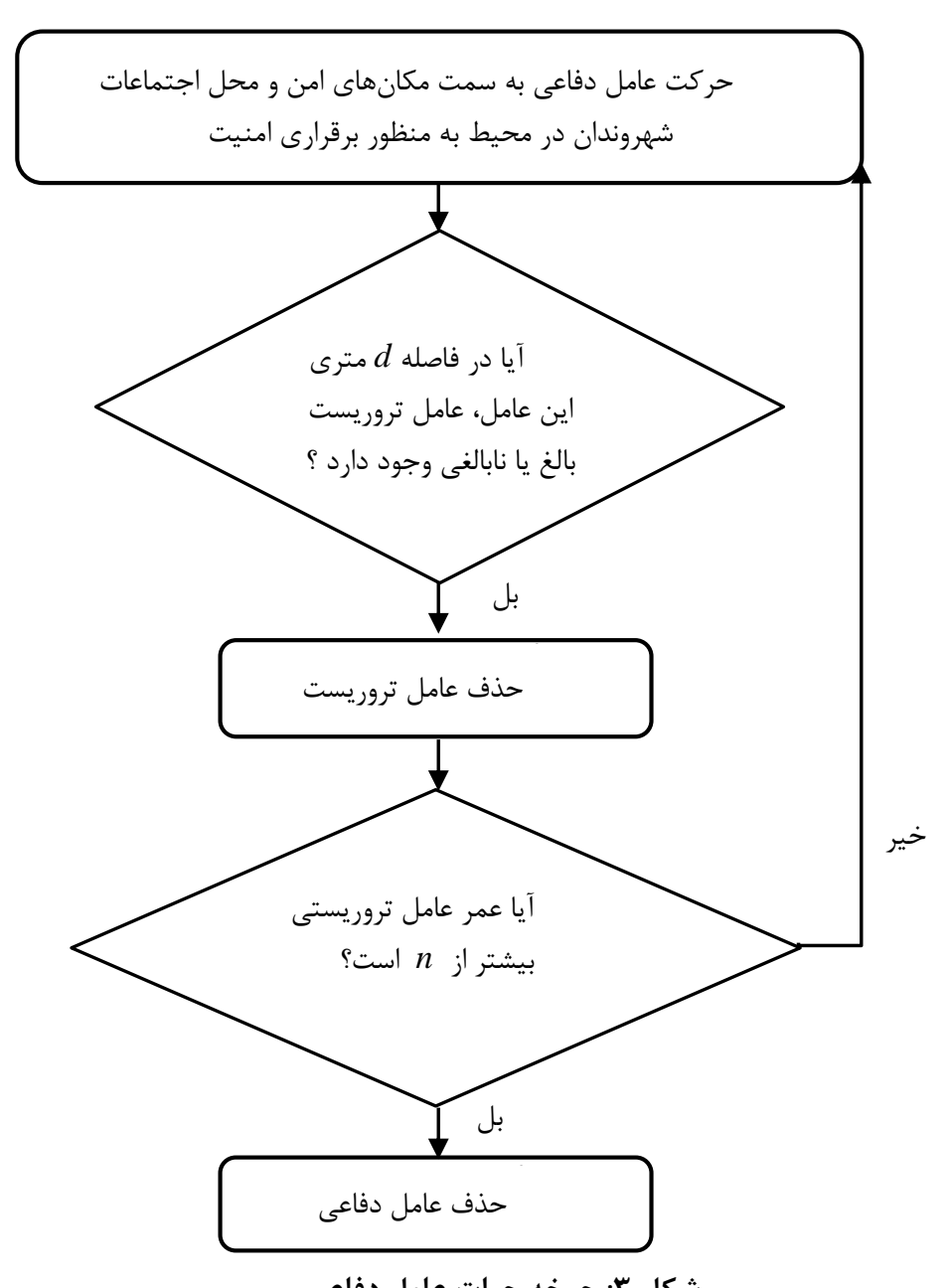


خروجى اضطرارى شهر با در نظر كرفتن سه پارامتر زير محاسبه مى كند:

مدتزمان لازم براى رسيدن به يناه گَاه با در نظر

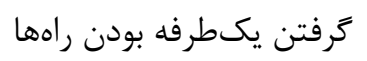

انتخاب مسيرهاى كم تردد بهمنظور راهنا رسيدن به نقاط

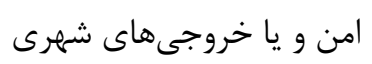

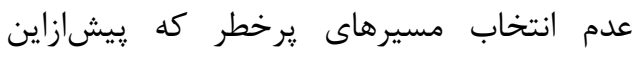

$$
\text { موردحمله واقع شده }
$$

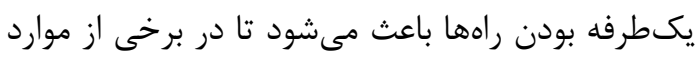

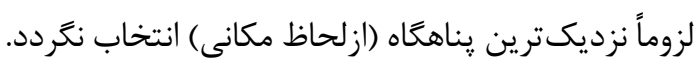

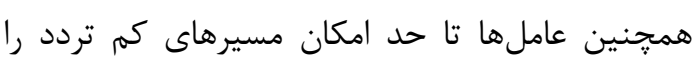

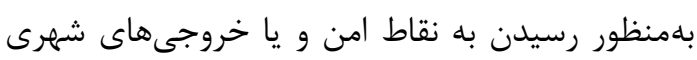

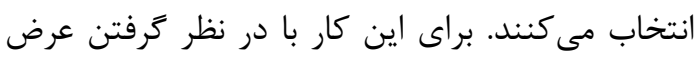

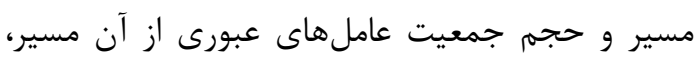

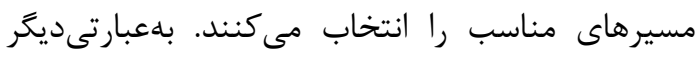

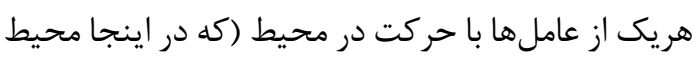
يك فضاى رسترى' متشكل از سطر و ستون تشكيل

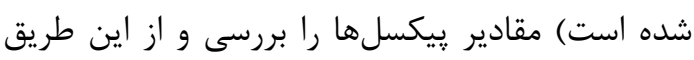

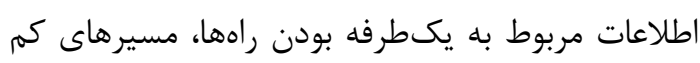

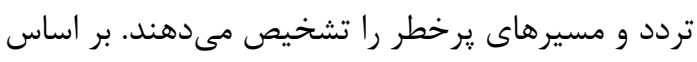

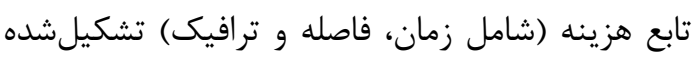

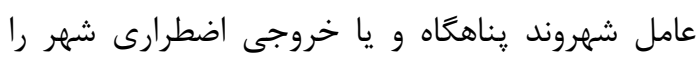

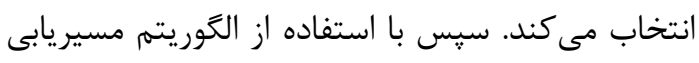

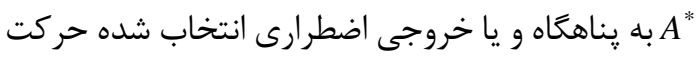

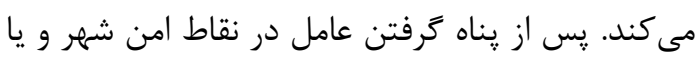

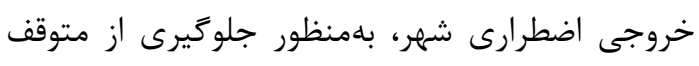

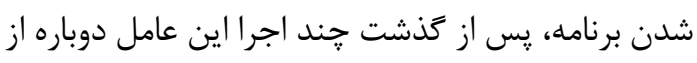

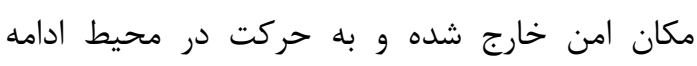
مى دهد.

\section{r-r- ع- عامل شهروندان}

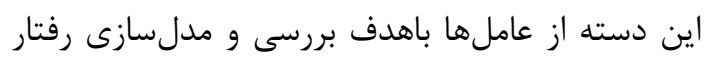

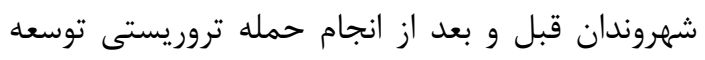

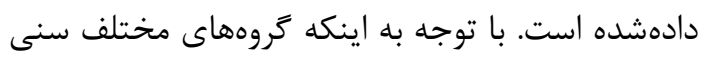

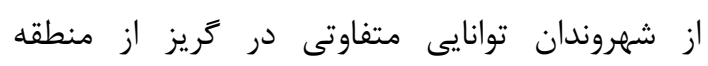
موردحمله واقعشده و نيز انتخاب مسيرهاى مناسب مناسب درئ

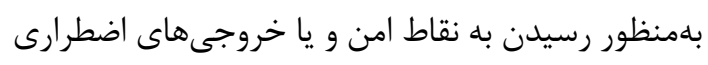

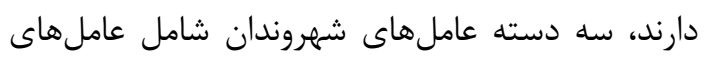

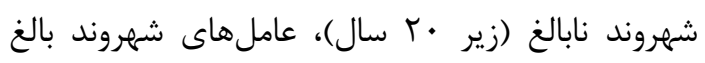

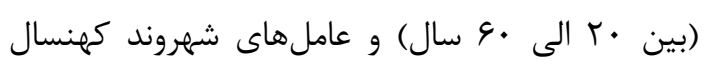

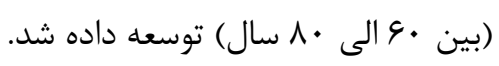

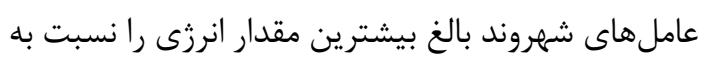

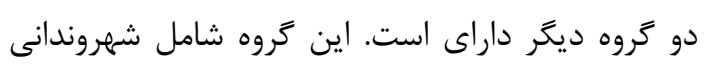

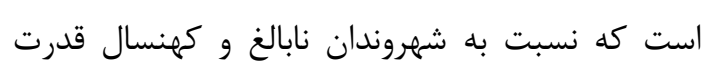
بيشترى بهمنظور كريز از منطقه موردحمله تروريستى و

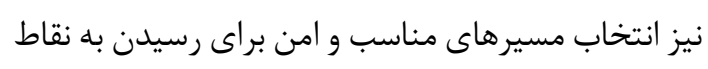

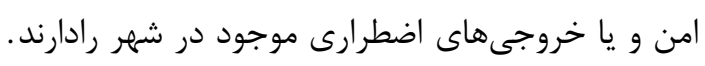

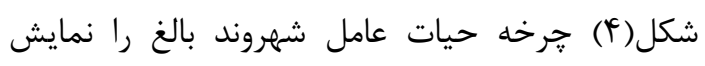
مىدهد. بهمنظور مدلسازى بهتر رفتار شهروندان إنهان اين

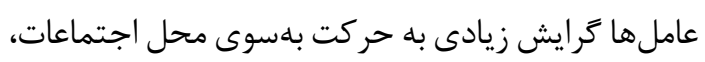

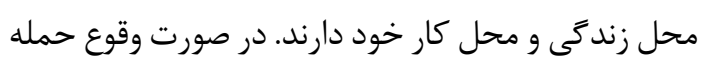
تروريستى، موقعيت محل موردحممله واقعشده از طريق دوريق

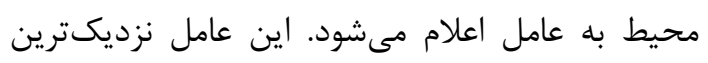

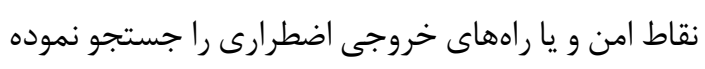

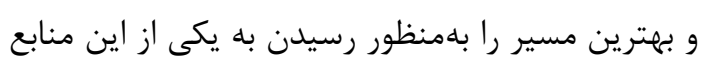

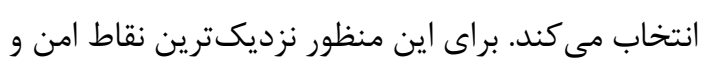

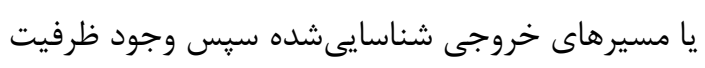

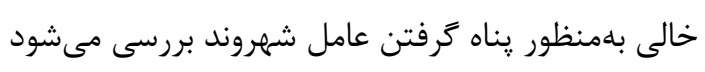

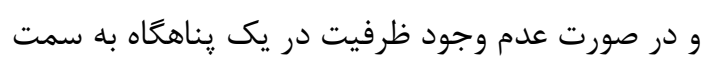

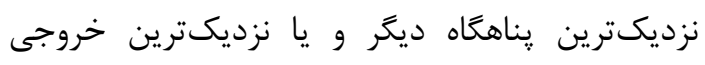

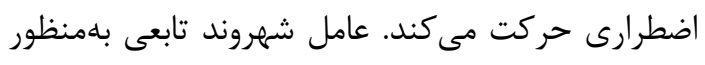

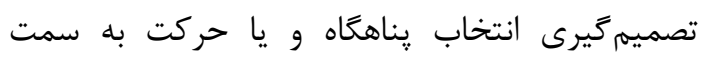




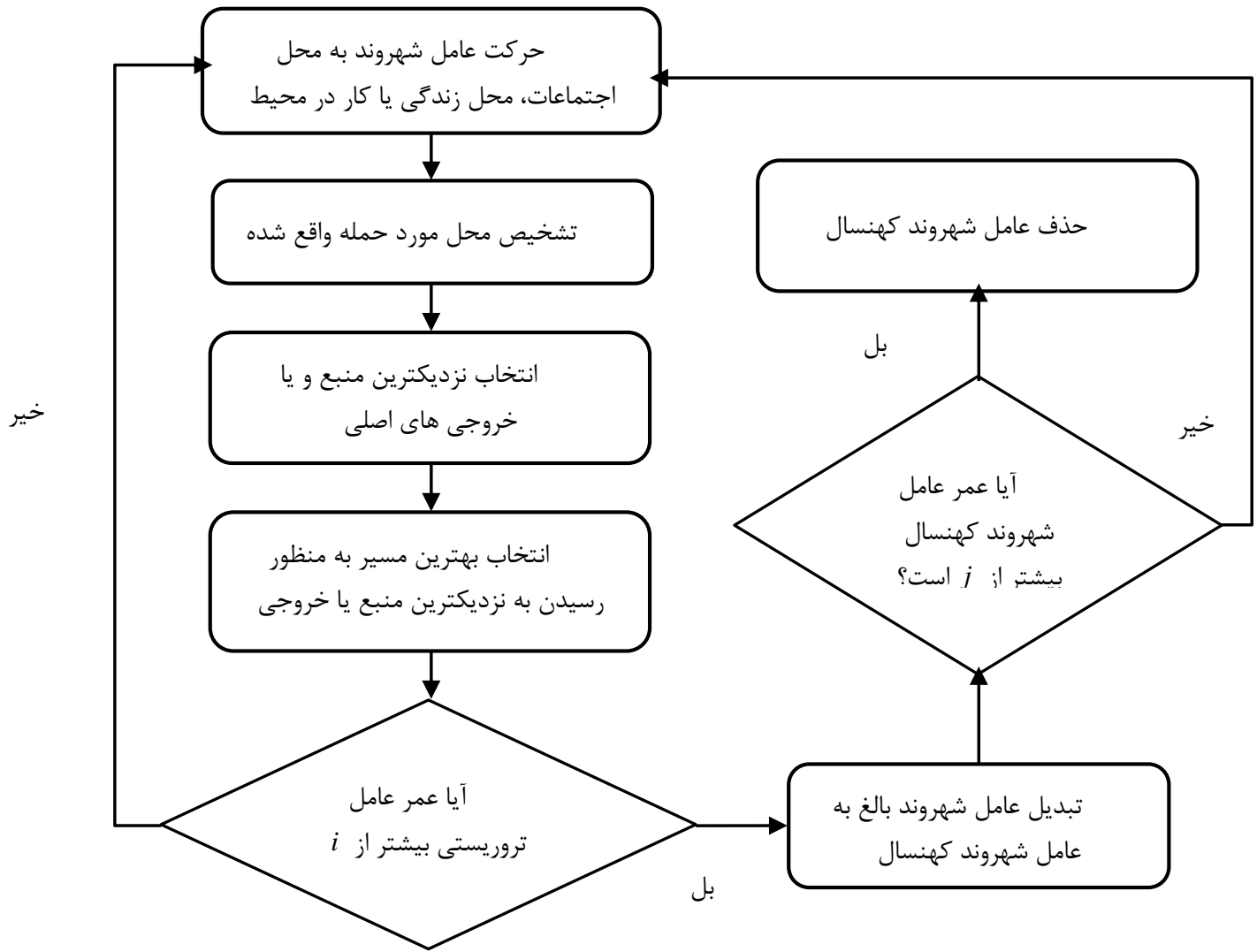

شكل f: جرخه حيات عامل شهروند بالغ

با توجه به توانايى متفاوت عامل هاى شهروند نابالغ، بالغ

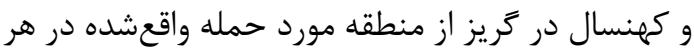
واحد از اجراى برنامه عامل شهروند بالغ يك يريكسل

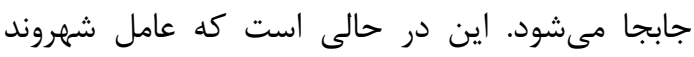
كهنسال براى جابجايى بهاندازه يك ييكسل در محيط به دو واحد اجراى برنامه زمان نياز داشته و عامل شهروند نابالغ در مدت زمان سه واحد اجراى برنامه بهاندازه يك ليك تيكسل در محيط جابجا مى شود. r- توسعه مدل عامل مبنا و تحليل نتايج در اين بخش ابتدا مجموعه دادههاى استفادهده در اين

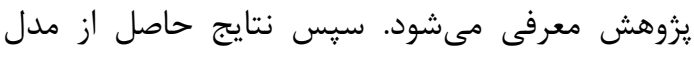

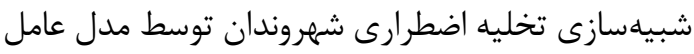
مبناى توسعه دادهشه ارائه خواهد شد. بهمنظور توسعه

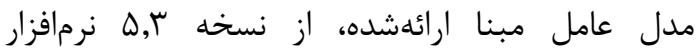
NetLogo نرمافزارهاى مدلسازى سيستمهاى جند عامله بهشمار
عامل هاى شهروند نابالغ، عامل هايى را شامل مىشوند كه نسبت به عاملهاى شهروند بالغ، داراى انرزى كمترى مىباشند. اين عاملها توانايى زايينى در گريز از منطقه موردحمله واقعشده و نيز توانايى زيايينى در انتخاب مسيرهاى مناسب بهمنظور رسيدن به نقاط امن و يا بائي خروجى هاى امن دارند. عاملهاى شهروند كهنسال شامل شهروندانى است كه نسبت به شهروندان بالغ، داراى انرزى كمترى هستند. اما اين دسته از عاملها نسبت به عاملهاى شهروند نابالغ قدرت بيشترى در انتخاب مسيرهاى مناسب (زيرا افراد مسن نسبت به خردسال قدرت تحليل بالاترى در انتخاب مسير دارند) و امن بهمنظور رسيدن به منابع هدف و نيز خروجى هاى امن، دارند. اين عاملها همانند عاملهاى شهروند نابالغ و بالغ نيز مىتوانند در جريان حمله تروريستى كشته شوند. لذا جرخه حيات اين عامل مشابه عامل شهروند بالغ است. 
با توجه به وظايفى كه براى آنها مشخص شده است به

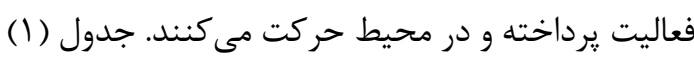

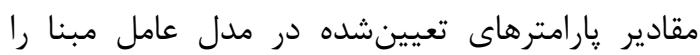
نمايش مى دهد.

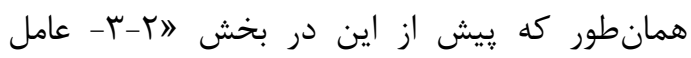

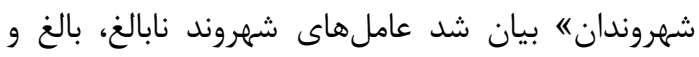
كهنسال توانايى متفاوتى در كريز از منطقه مورد حمله

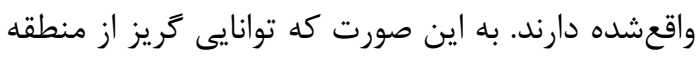

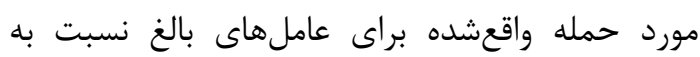
عاملهاى كهنسال و عاملهاى كهنسال نسبت به بهائ عامل هاى نابالغ بيشتر است. لذا انرزى اوليه عامل هاى كاى

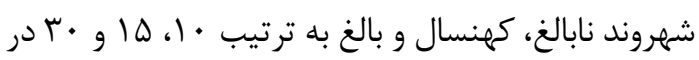

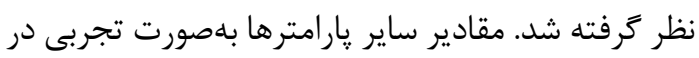

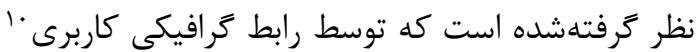

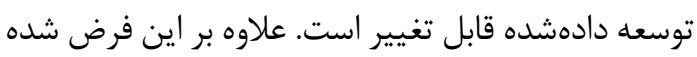

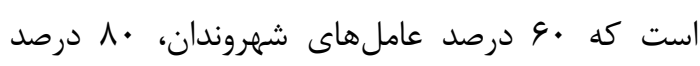
عاملهاى تروريستى و •^ درصد عاملهاى دفاعى كرايش به حركت به سمت مناطق شلوغ دارئ دارند. انكَيزه

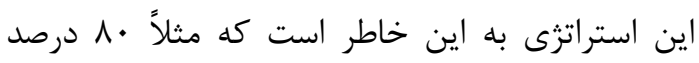

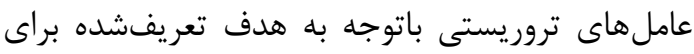

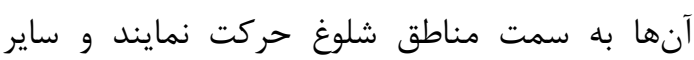

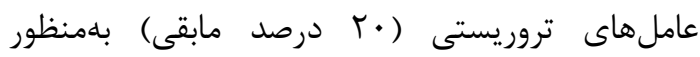
جستجوى مناطق غير شلوغ اما مستعد براى انجام حمله

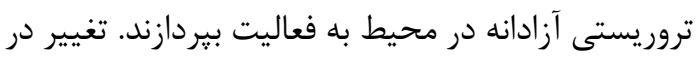

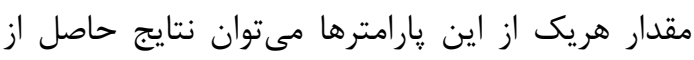

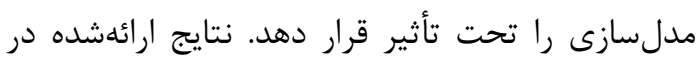

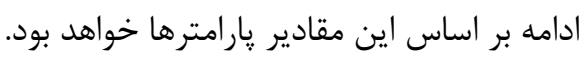

${ }^{6}$ Peter E. Hart

${ }^{7}$ Nils Nilsson

${ }^{8}$ Bertram Raphael

${ }^{9}$ Minimization

${ }^{10}$ Graphic User Interface
مىرود كه توسط دانشگاه اورى ويلنسكى' با يروانه

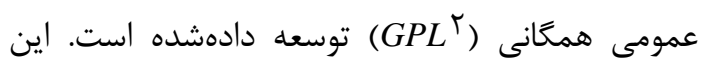
نرمافزار براى شبيهسازى سيستمهاى پيڤيحيده طرحى شده است. نرمافزار NetLogo با زبان جاوا نوشته شده

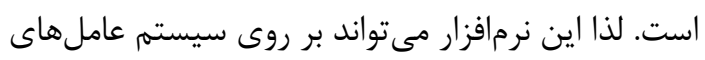

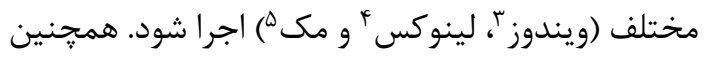

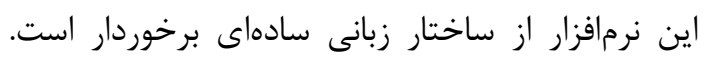

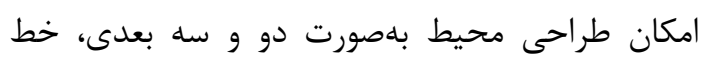

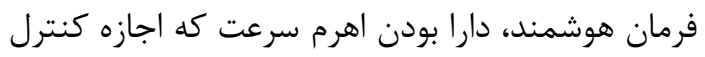
سرعت مدل و مشاهده خروجى را با دقت بيشتر مى دهدهد،

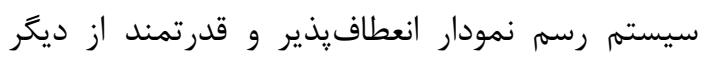

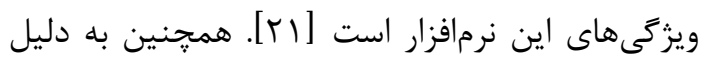

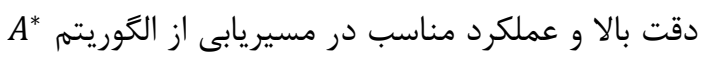

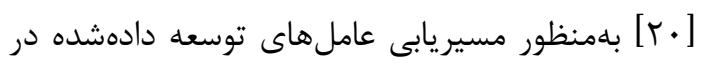

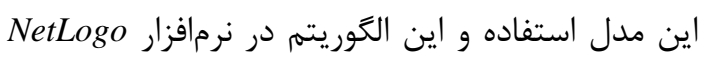

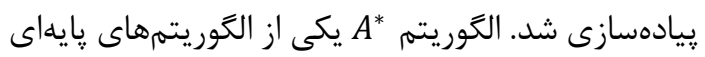

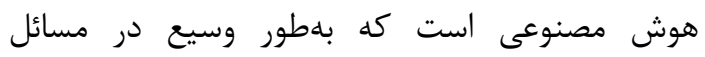

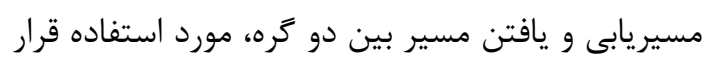

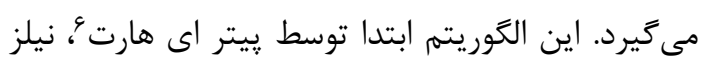

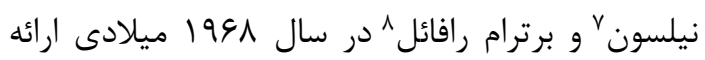

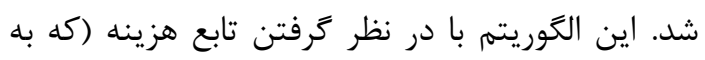

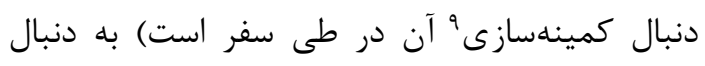

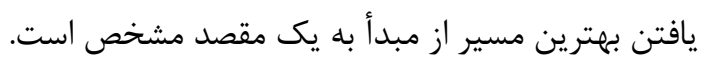

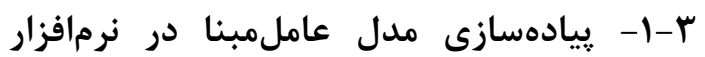

NetLogo در اين تحقيق براى توزيع اوليه عاملهاى توسعه

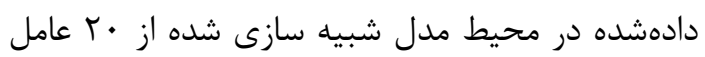

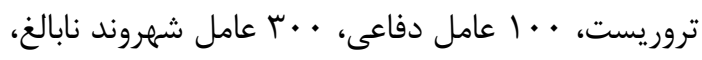

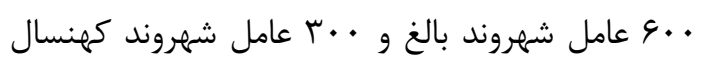

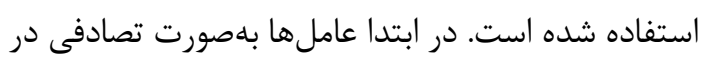

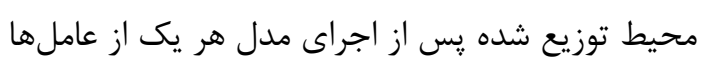

${ }^{1}$ Uri Wilensky: https://ccl.northwestern.edu/uri/

${ }^{2}$ General Public Licence

${ }^{3}$ Windows

${ }^{4}$ Linux

${ }^{5} \mathrm{Mac}$ 
جدول ا: مقادير يِيشفرض يارامترهاى مدل عامل مبنا

\begin{tabular}{|c|c|}
\hline ا. انفر & تعداد اوليه عاملهاى تروريست \\
\hline 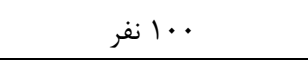 & تعداد اوليه عامل هاى دفاعى \\
\hline 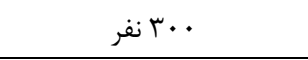 & تعداد اوليه عاملهاى شهروند نابالغ \\
\hline 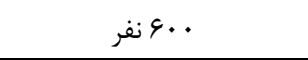 & تعداد اوليه عاملهاى شهروند بالغ \\
\hline 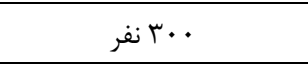 & تعداد اوليه عامل هاى شهروند كهنسال \\
\hline 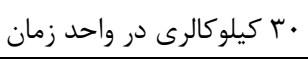 & انرزى اوليه عاملهاى دفاعى \\
\hline • م كيلو كالرى در واحد زمان & انرزى اوليه عاملهاى تروريستى \\
\hline • ا كيلو كالرى در واحد زمان & انرزى اوليه عاملهاى شهروند نابالغ \\
\hline 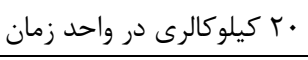 & انرزى اوليه عاملهاى شهروند بالغ \\
\hline ها كيلو كالرى در واحد زمان & انرزى اوليه عاملهاى شهروند كهنسال \\
\hline 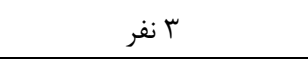 & تعداد عاملهاى تروريست لازم جهت انجام حمله تروريست \\
\hline 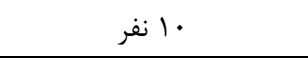 & تعداد عاملهاى شهروند لازم جهت انجام حمله تروريست \\
\hline 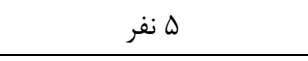 & حداكثر تعداد عاملهاى دفاعى لازم جهت انجام حمله تروريست \\
\hline F كيلوكالرى در واحد زمان F. & حداقل انرزى عاملهاى تروريستى بلمنظور انجام حمله تروريستى \\
\hline ه ه كيلوكالرى در واحد زمان & حداقل انرزى جهت زنده ماندن عاملها \\
\hline 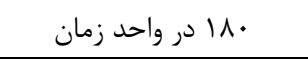 & تعداد اجراهايـى كه شهروندان در يناهگًاهها مانده و خارج نمىشوند \\
\hline 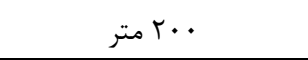 & حداقل شعاع بهمنظور برقرارى ارتباط تروريستها با يكديگر \\
\hline
\end{tabular}

كيلومترمربع و همجنين شش خروجى اضطرارى موجود در منطقه 9 استفاده شد. يس از تهيه دادههاى موردنظر اين دادهها بهمنظور تشكيل محيط مدل مكانى عامل مبنا مورد استفاده قرار

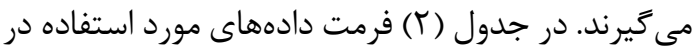
اين يروزه نمايش داده شده است. خروجىهاى اضطرارى

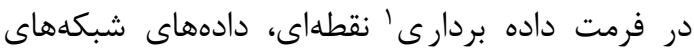

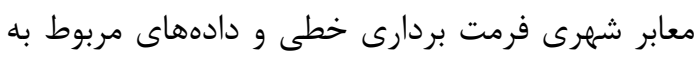
نقاط شلوغ، يناهگاهها و نقاط امن در فرمت داده بردارى يلى گونى مورد استفاده قرار گرفت. شكل (؟) مراحل

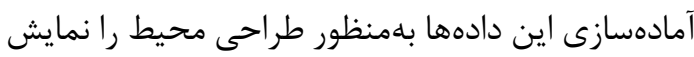

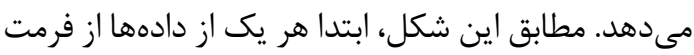
بردارى به فرمت رسترى تبديل شد و سيس بهمنظور

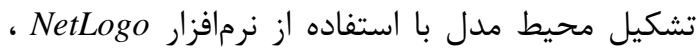
فرمت رسترى دادهها به فرمت اسكى گ تبديل شد. r-r- دادههاى مورد استفاده محدوده مورد مطالعه منطقه 9 شهر تهران به مساحت لهو

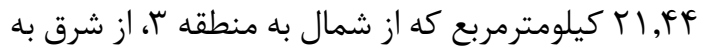

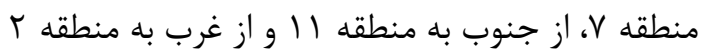
متصل است. شكل (ه) دادههاى مورد استفاده منطقه 9 شهر تهران را نمايش مى مهد. همجنين دادههاى شبكه معابر شهرى منطقه \& دربردارنده اطلاعاتى ييرامون عرض راههاى شهرى بامنظور محاسبه ترافيك جمعيت

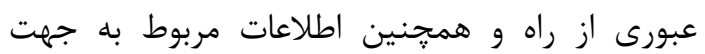
خيابانهاى يكىطرفه با توجه به اهميت اين اطلاعات در مسيريابى عاملها مورد استفاده قرار گرفتند. علاوه بر اين دادهاى نقاط يرجمعيت شهرى شامل مراكز خريد،

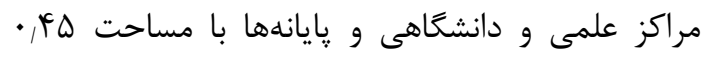

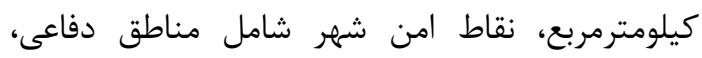

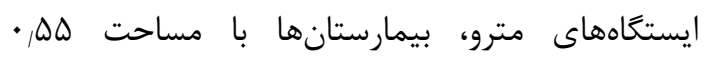




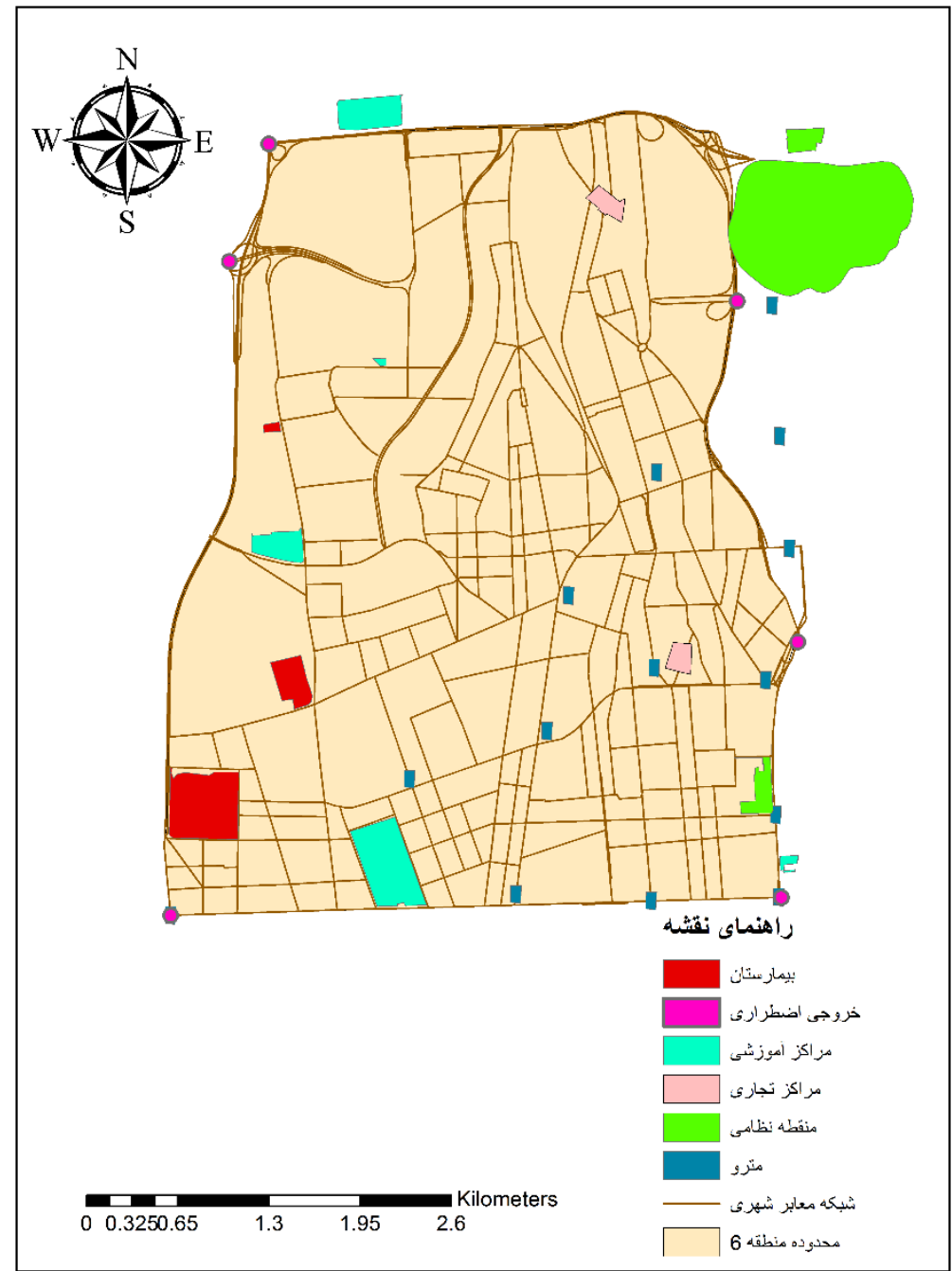

شكل ه: دادههاى مورد استفاده در مدل شبيهسازى عامل مبناى تخليه اضطرارى شهروندان

جدول r: فرمت دادههاى مورد استفاده

\begin{tabular}{|c|c|}
\hline فرمت دادهها & دادهها \\
\hline نقطه & خروجى هاى اضطرارى \\
\hline خط & شبكه معابر شهرى \\
\hline يلى گون & نقاط شلوغ، پِناهگاهها و نقاط امن \\
\hline
\end{tabular}




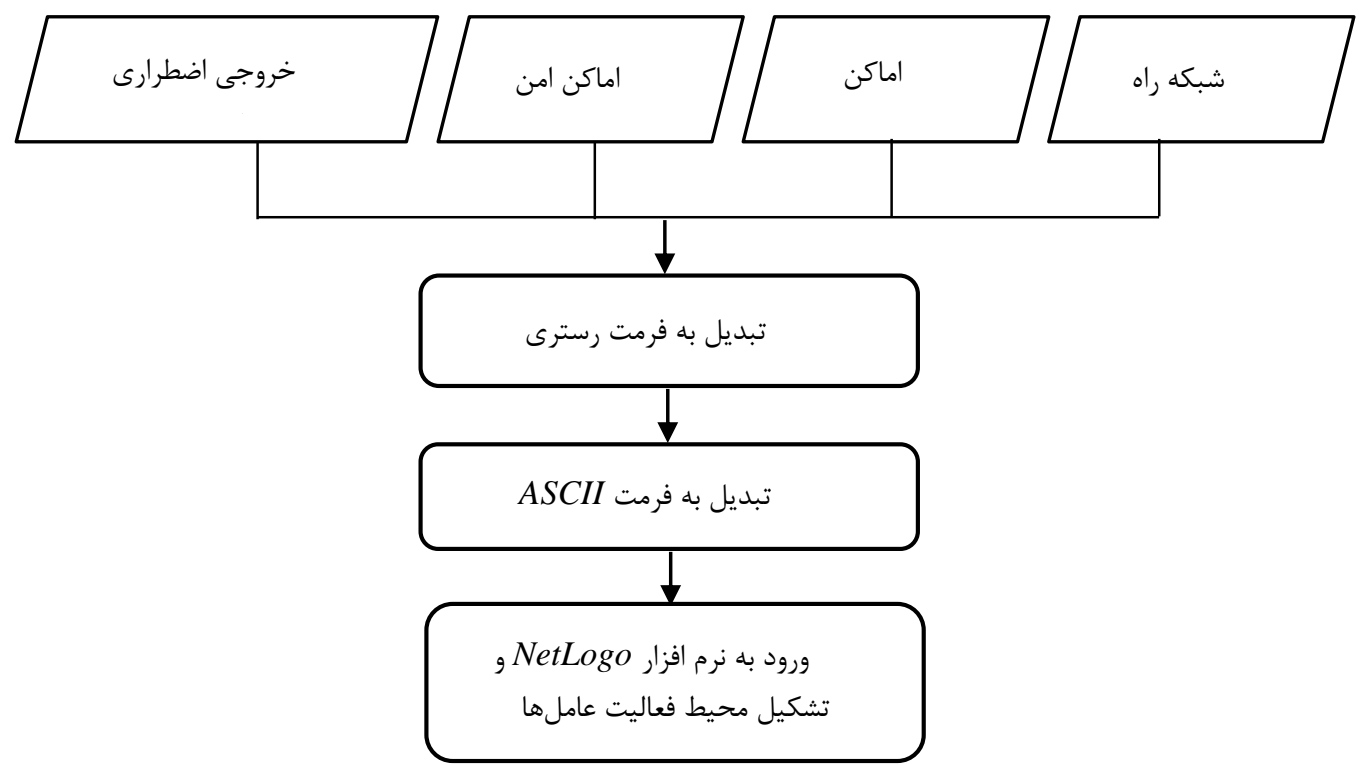

شكل 9: مراحل آمادهسازى دادهها بهمنظور طراحى محيط مدل

است. اين موضوع به اين دليل است كه تعداد عاملهاى حماى شهروند كهنسال حضور داشته در منطقه مورد حمله واقعشده بيشتر از تعداد عاملهاى شهروند نابالغ است. در ساير حملات تروريستى انجامشده، درصد عاملهاى

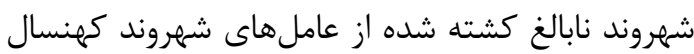
بيشتر است. همجنين به دليل توانايى بالاى عاملهاى شهروند بالغ (نسبت به عاملهاى شهروند نابالغ و كهنسال) در كريز از منطقه مورد حمله واقعشده، تعداد عاملهاى شهروند بالغ كشتهشدىان در تمامى حملات تروريستى انجامشده در منطقه از عاملهاى شهروند

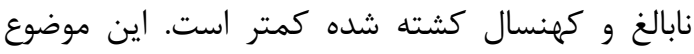

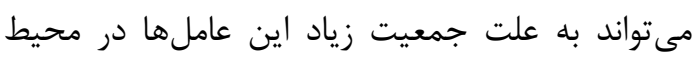
باشد. در مدل شبيهسازى اجراشده با توجه به مقادير اوليه پارامترهاى مدل كه در جدول (1) تشريح شده

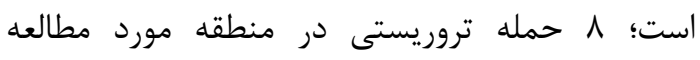
ييشبينى شد. در طول اين حملات تروريستى انجامشده

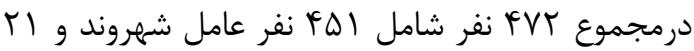
عامل دفاعى كشته شدند. عامل هاى شهروند كشته شده در اين حملات شامل 19 19 عامل شهروند نابالغ، عامل شهروند بالغ و • IV عامل شهروند كهنسال است. با توجه به مقادير اوليه هارامترهاى در نظر كرفتهشده در

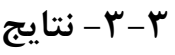
شكلهاى (V) و (N) به ترتيب تعداد عاملها در . ... اجراى مدل و درصد عامل هاى شهروند كشتهشده (تعداد عاملهاى كشته شده به تعداد عاملهاى هر دسته در

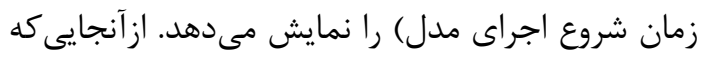

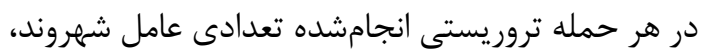

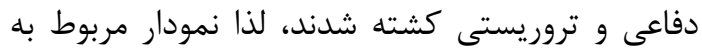
جمعيت هريك از اين عاملها همواره نزولى است. اولين

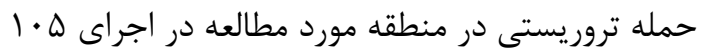
انجام شد. در اين حمله ؟,1 درصد عامل شهروند نابالغ،

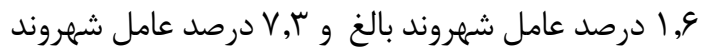

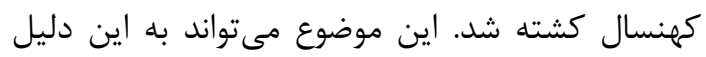
باشد كه انرزى اوليه عاملهاى شهروند بالغ از عاملهاى شهروند كهنسال و انرزى اوليه عاملهاى شهروند كهنسال از عامل هاى شهروند نابالغ بيشتر است (انرزى أرى النه اوليه عاملها در جدول ا تشريح شده است). در حملات

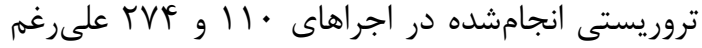

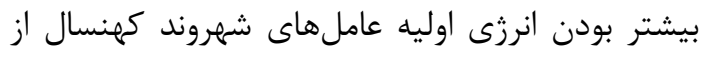

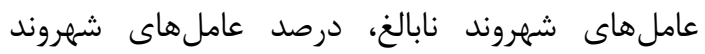
كهنسال كشته شده از عاملهاى شهروند نابالغ بيشتر 
رسيدن به نزديك خروجى و يا مكان امن را انتخاب نموده

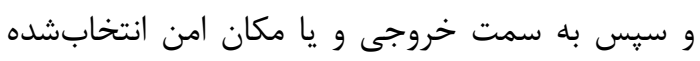
حركت مى كنند. در حين اين تخليه اضطرارى حمله

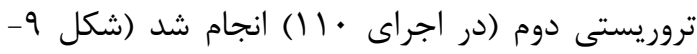

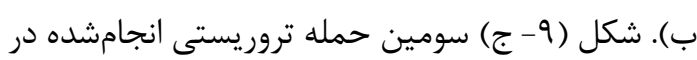

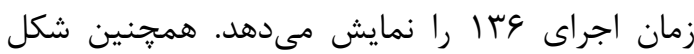

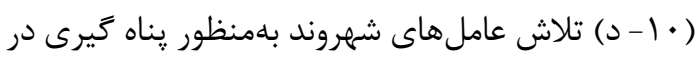

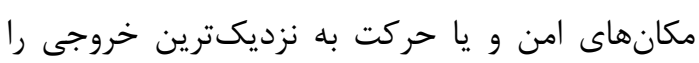
نمايش مىدهد كه در اين فاصله جهارئه تروريستى در زمان اجراى MVY توجه از بررسى نقشههاى ارائهشده در شكل (9) متمركز بودن حملات تروريستى است. تقريباً تمامى حملات تروريستى انجامشده در منطقه مربوط به بخش مركزى بونى

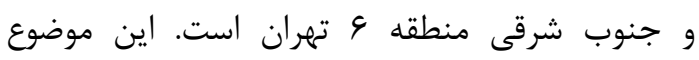
مى تواند به دليل عدم دسترسى مناسب به خروجى هنهاى

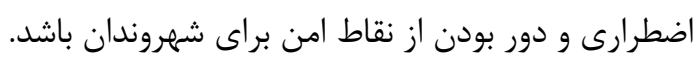

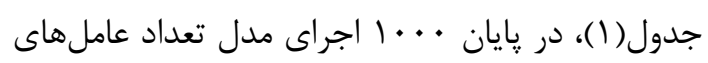
تروريستى به صفر مىرسد. لذا به نظر مىرسد كه تعداد

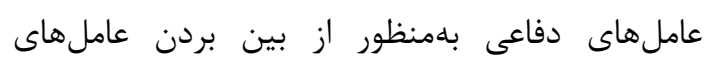
تروريستها كافى نيست. شكل (9) نقشه مكانهاى موردحمله واقعشده بعد از

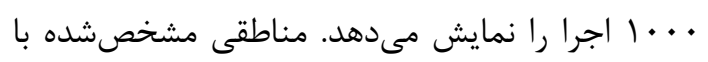
رنت قرمز محل هاى موردحمله واقعشده مىباشند. شكل (9-الف) توزيع اوليه عامل ها در محيط را نمايش مى دههد. يس از اجراى مدل شبيهسازى، عاملهاى شهروندان در در

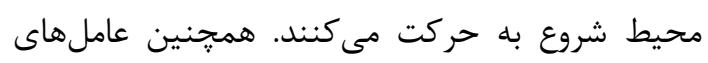
تروريستى با حركت به سمت مكانهاى يرجمعيت و و بهرئ

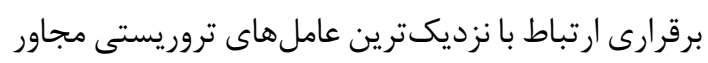

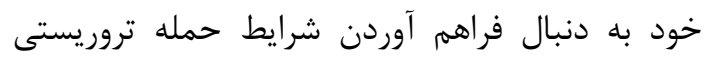

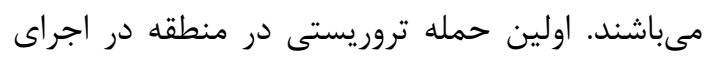

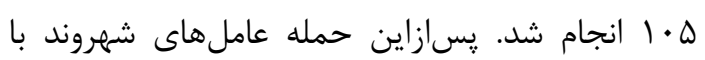

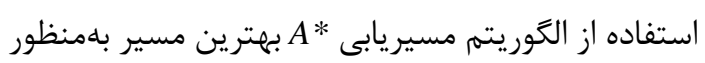

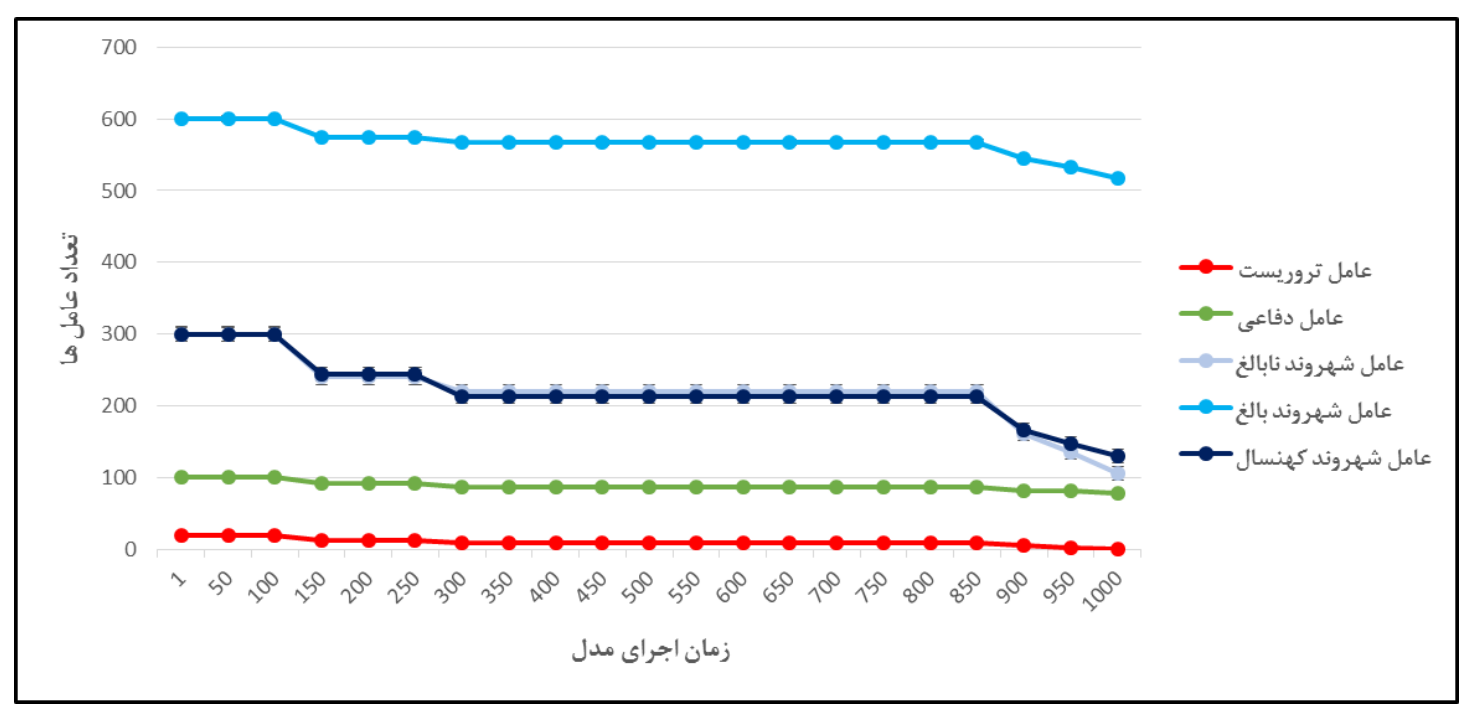

شكل \: تعداد عاملها يس از •..1ا اجراى مدل عامل مبناى تخليه اضطرارى 


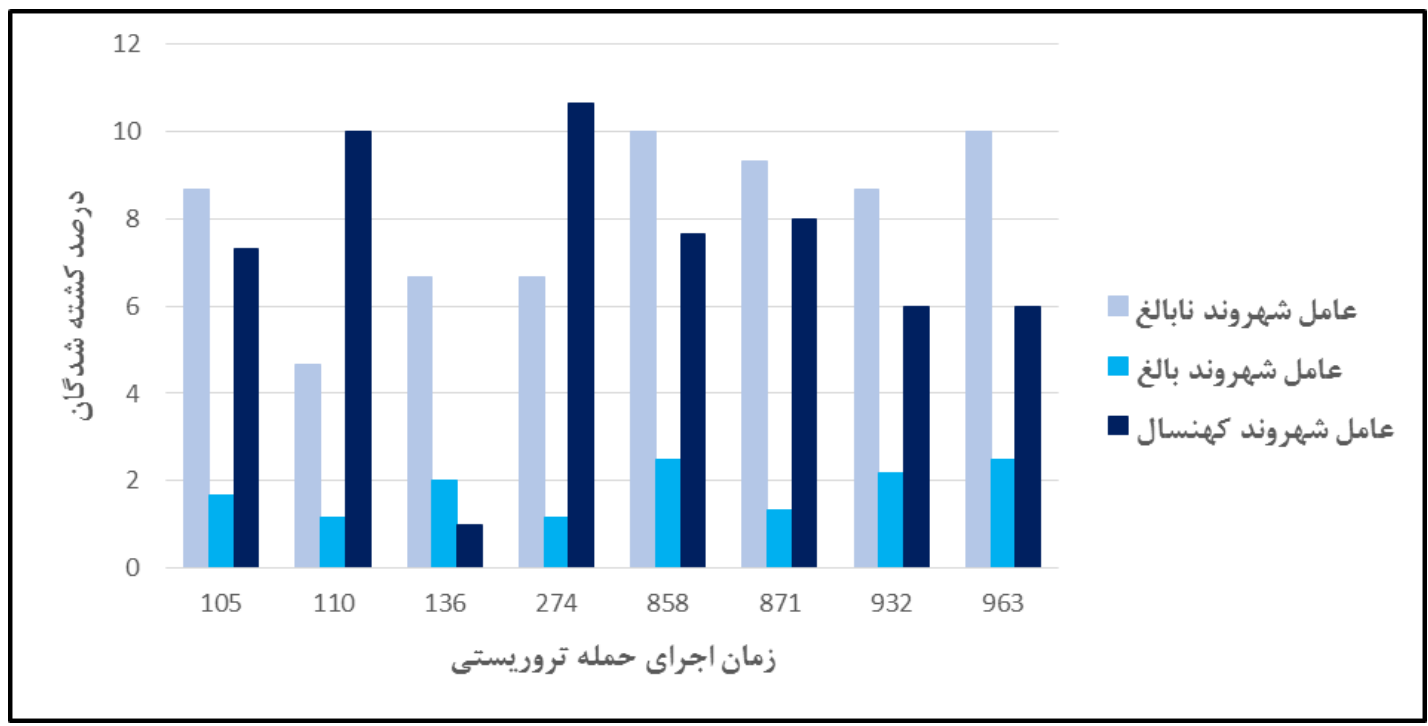

شكل ^: درصد عامل هاى كشتهشده

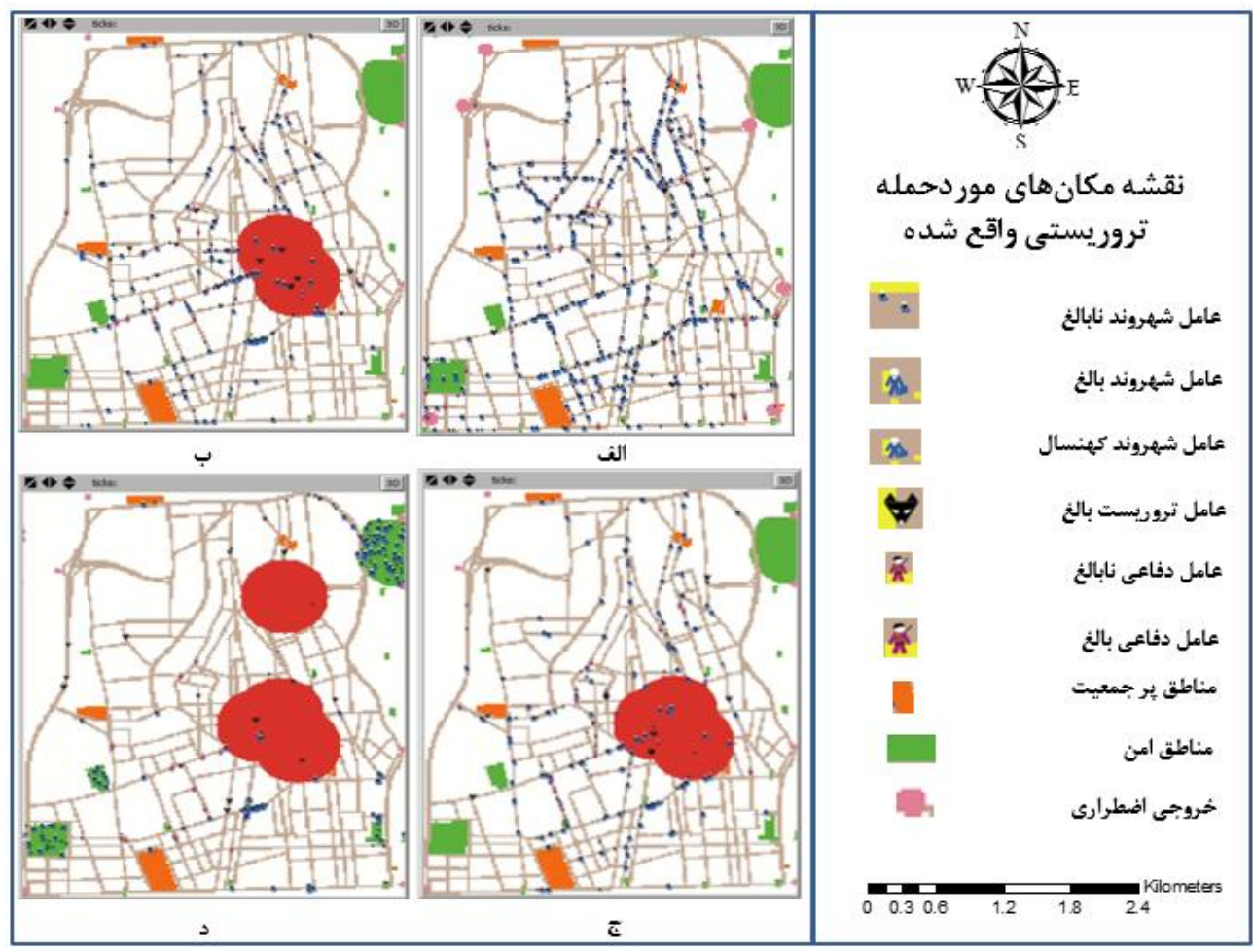

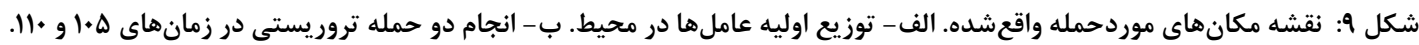

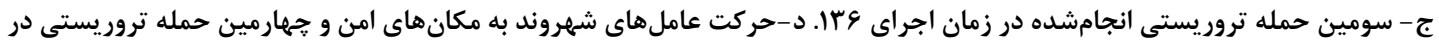
زمان اجراى TVF. 
مدل) در صورت دو برابر شدن تعداد عاملهاى تروريست

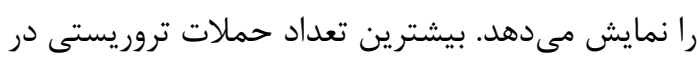
•ها زمان اجراى ابتدايى مدل بوده، لذا نمودار تعداد

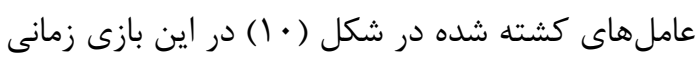

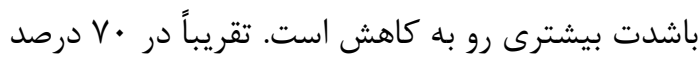

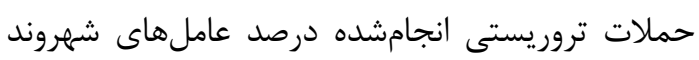

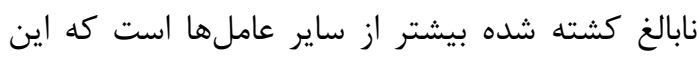

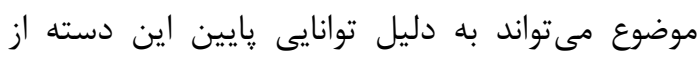

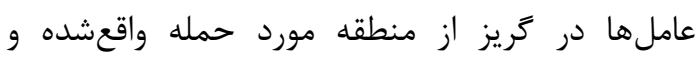

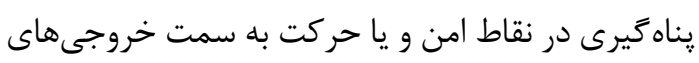

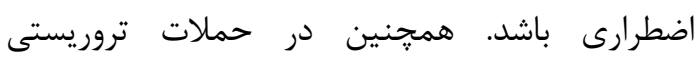

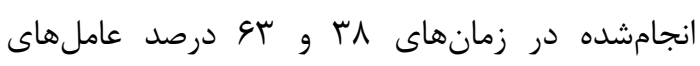
شهروند بالغ كشته شده بيشتر از عاملهاى زماى شهروند كهنسال است. همجنين در زمان اجراى باى

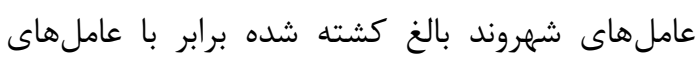
شهروند كهنسال است. اين موضوع مىتواند به دلي دليل

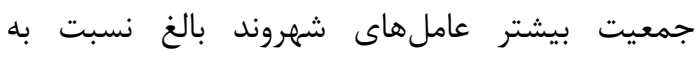
عامل هاى شهروند كهنسال باشد.

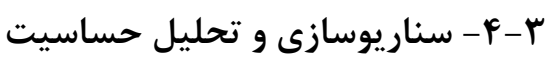

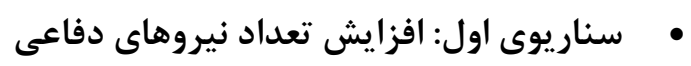
يكى از قابليتهاى مدل عامل مبناى توسعه دادهشده

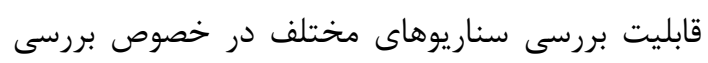

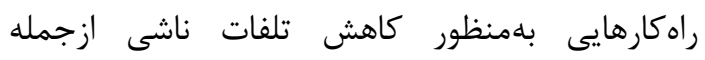

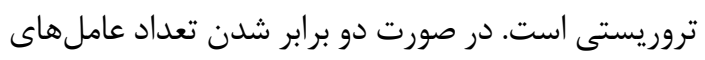

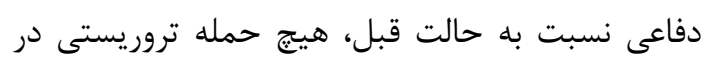

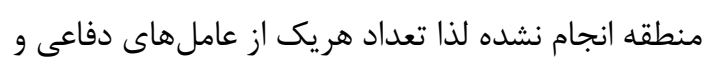

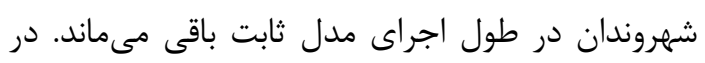
نتيجه به نظر مىرسد كه با افزايش تعداد نيروهاى دفاعى دمانى در منطقه مىتوان امكان حمله تروريستى و تعداد بنداد كشتهشدكان را به صفر رساند.

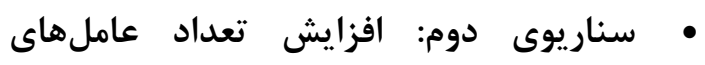
تروريست

شكلهاى (• (1) و (1) ) به ترتيب تعداد عامل ها و درصد عاملهاى شهروند كشتهشده (تعداد عاملهاى كاى كشته شده به تعداد عاملهاى هر دسته در زمان شروع اجراى (تصدئ

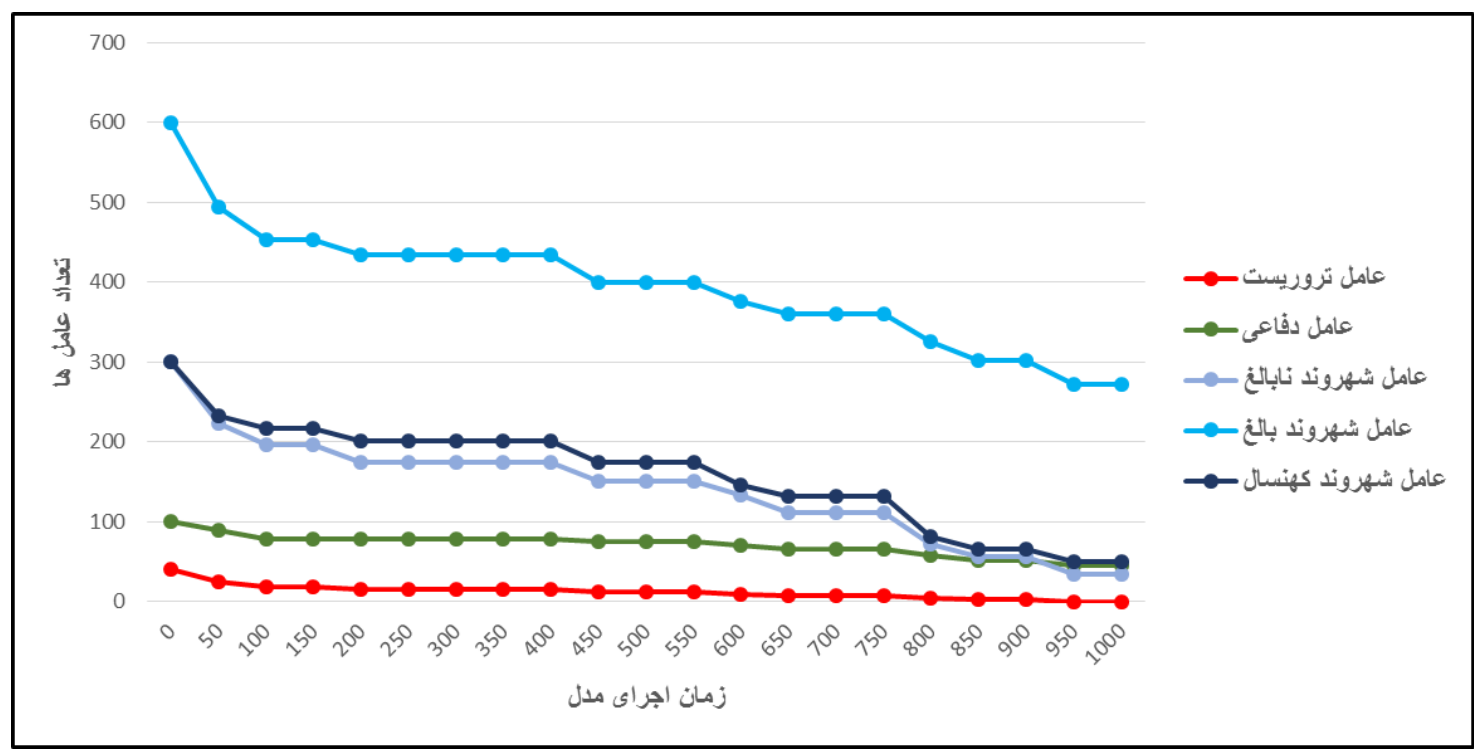

شكل •ا: تعداد عاملها يس از دو برابر نمودن تعداد عاملهاى تروريست در اجراهاى مختلف 


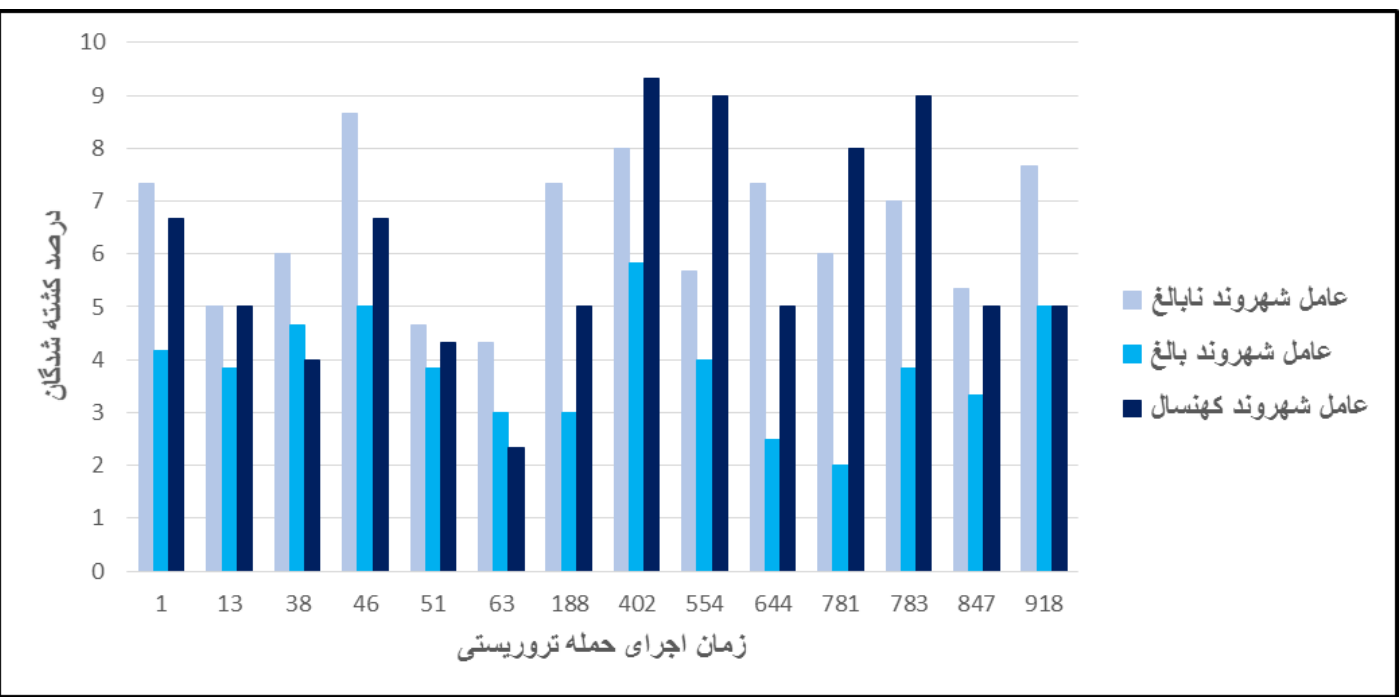

شكل (ا: درصد عاملهاى كشتهشده (تعداد عاملهاى كشته شده به تعداد عاملهاى هر دسته در زمان شروع اجراى مدل)

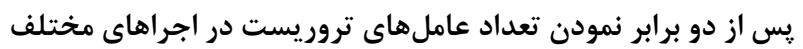

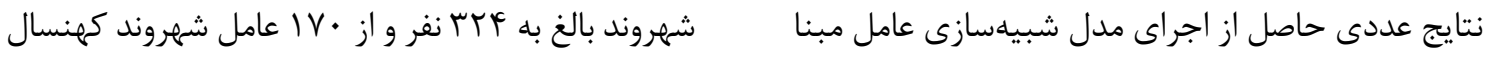

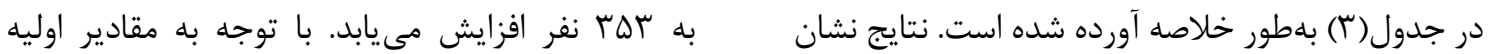

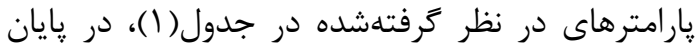

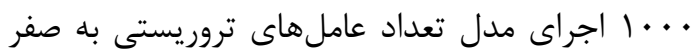

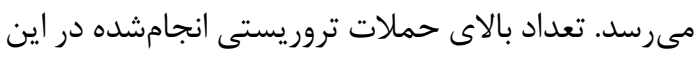
سناريو و در نتيجه افزايش عاملهاى كشته شده بيان

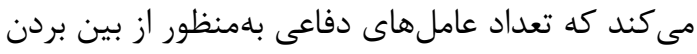
عامل هاى تروريستها كافى نيست.

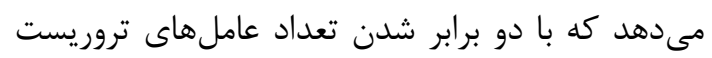

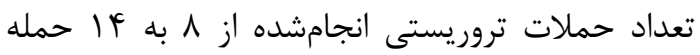

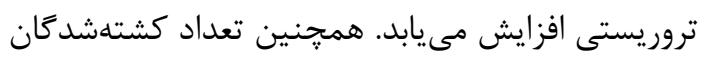

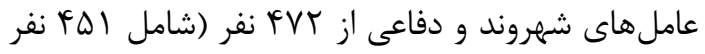

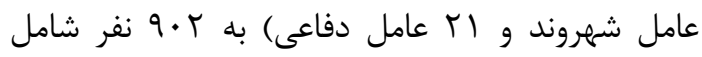

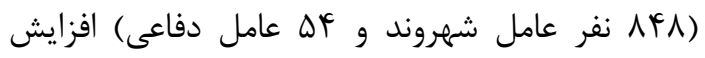

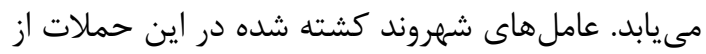

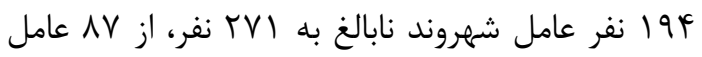

جدول r: نتايج حاصل از دو برابر شدن تعداد عامل هاى تروريست

\begin{tabular}{|c|c|c|}
\hline نتايج حاصل از دو برابر شدن & نتايج تنظيمات اوليه & نوع يارامترهاى بررسى شده \\
\hline |f احمله & 1 حمله & تعداد حملات تروريستى انجامشده \\
\hline 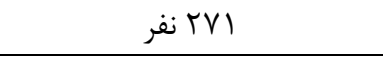 & 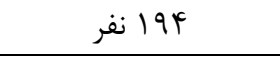 & تعداد عامل هاى شهروند نابالغ كشته شده \\
\hline 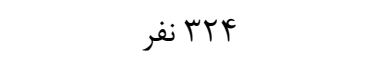 & 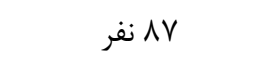 & تعداد عامل هاى شهروند بالغ كشته شده \\
\hline 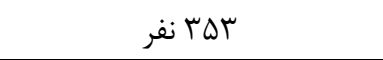 & 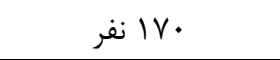 & تعداد عاملهاى شهروند كهنسال كشته شده \\
\hline 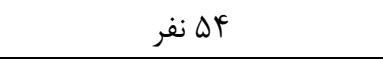 & ا ا ا نفر & تعداد عاملهاى دفاعى كشته شده \\
\hline 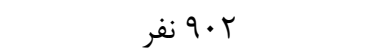 & 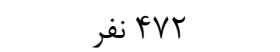 & مجموع عاملهاى كشته شده (شهروند+دفاعى) \\
\hline
\end{tabular}




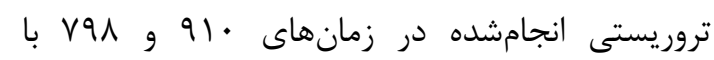

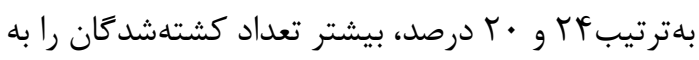
خود اختصاص داده است. علاوهبراين ازآنجايىكه عاملهاى تروريستى شركت كننده در حمله تروريستى

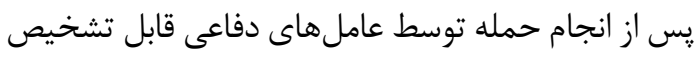

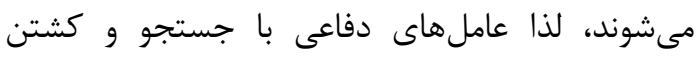

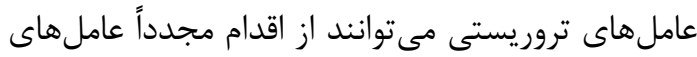
تروريستى شناسايىشده جهت انجام حمله تروريستى نه

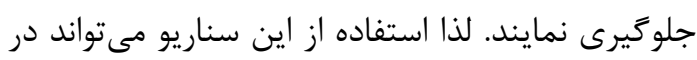
كاهش تعداد حملات تروريستى نقش بهسزايى داشته

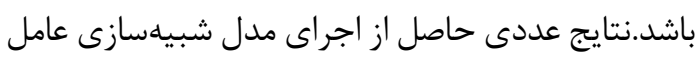

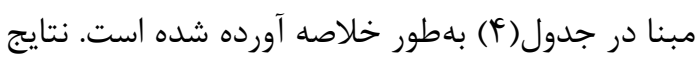
نشان مىدهد كه در صورت تخصيص •ع درصد تعداد

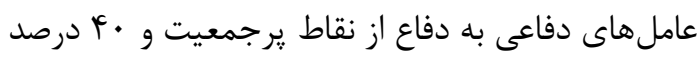
آنها به جستجو و كشف عامل دهاع به دواع إن نعداد حملات تروريستى انجامشده از ^ به ه حمله تروريستى كاهش مى يابد. همجنين تعداد كشتهشد

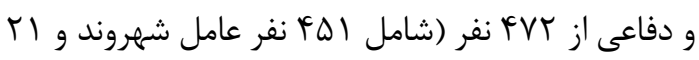
عامل دفاعى) به TVY نفر شامل ( • (ب نفر عامل شهروند و و أ عامل دفاعى) افزايش مى يابد. عامل هاى شهروند

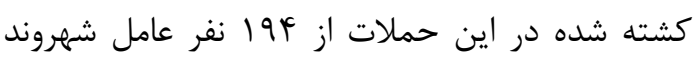

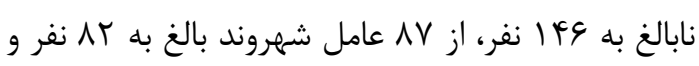

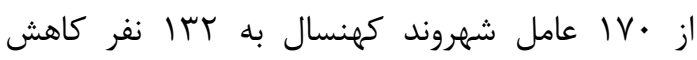

مى يابد.
• سناريوى سوم: تخصيص •و درصد تعداد عامل هاى دفاعى به دفاع از نقاط يرجمعيت و

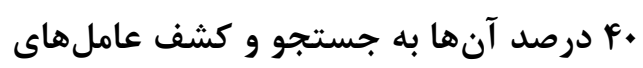
تروريست

ييش از اين بخش، نتايج حاصل از مدل كه در بخش (ب-

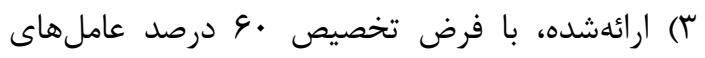

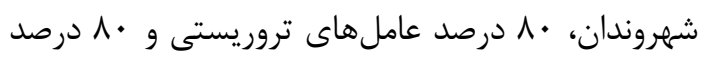
عامل هاى دفاعى گرايش به حركت به سمت مناطق شلوغ

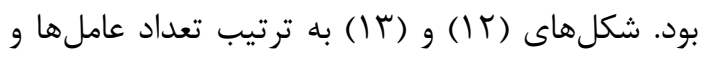

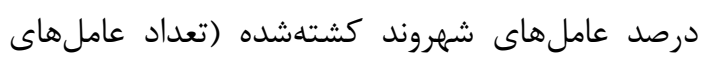
كشته شده به تعداد عاملهاى هر دسته در زمان شروع اجراى مدل) در صورت تخصيص •ع درصد تعد تعداد

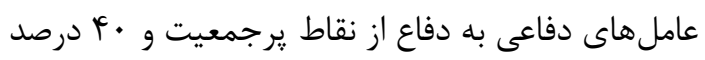

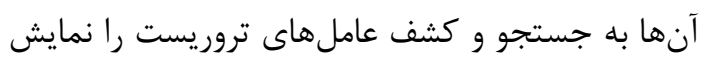
مىدهد. بيشترين تعداد حملات تروريستى در يكسوم

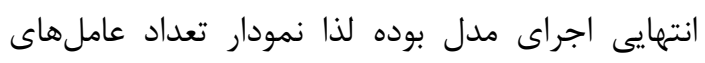
كشته شده در شكل (Y) در اين بازى زمانى با شدت بيشترى رو به كاهش است. تقريباً در • ع درصد حملات تروريستى انجامشده درصد عاملهاى شهروند نابالغ كشته شده بيشتر از ساير عاملها است كه اين موضوع

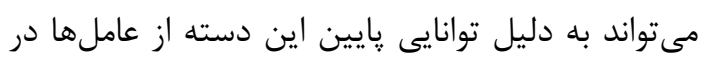

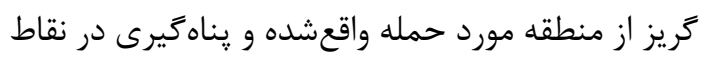
امن و يا حركت به سمت خروجىهاى اضطرارى باشد.

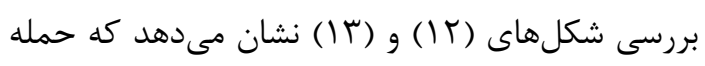

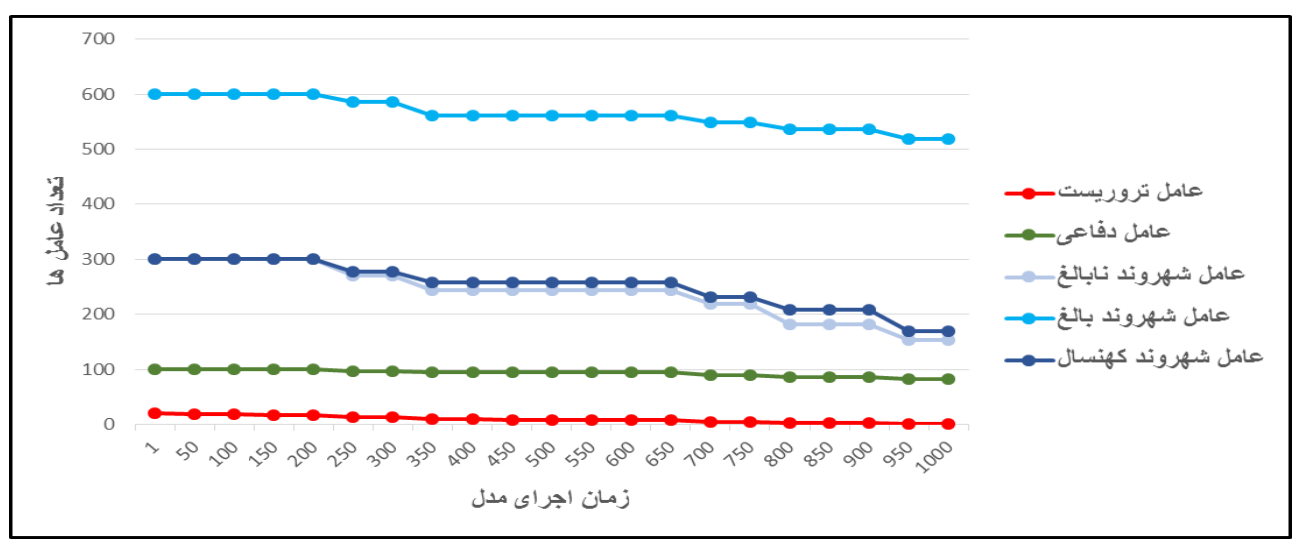

شكل rا: تعداد عاملها در صورت تخصيص •و درصد تعداد عامل هاى دفاعى به دفاع از نقاط يرجمعيت و •F درصد آنها به جستجو و كشف عاملهاى تروريست 


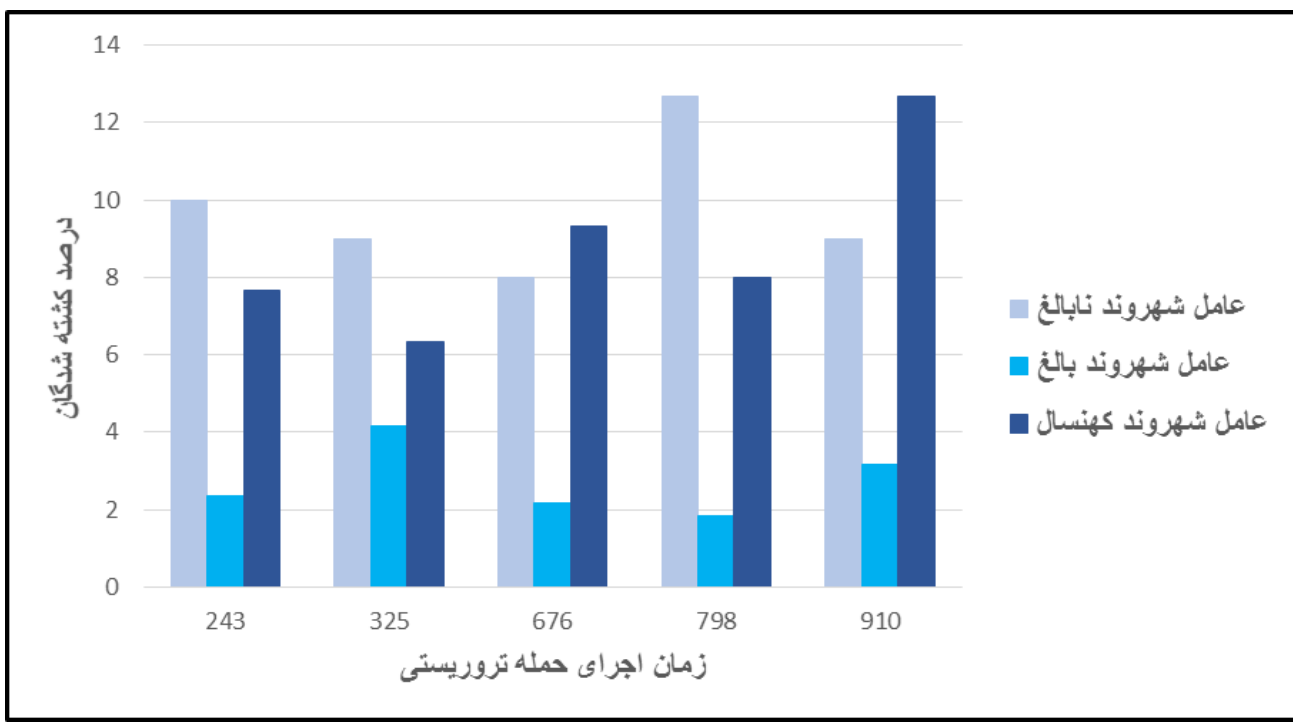

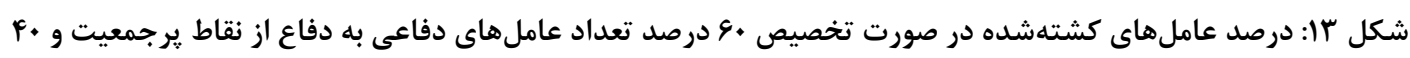

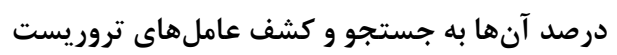

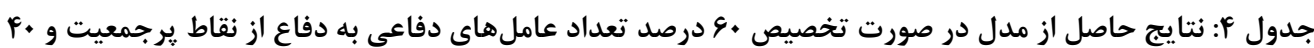
درصد آنها به جستجو و كشف عامل هاى تروريست

\begin{tabular}{|c|c|c|}
\hline 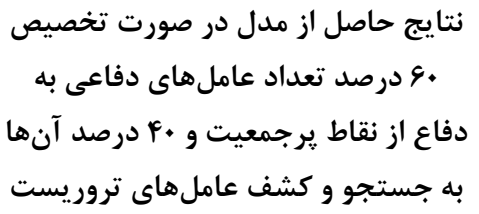 & نتايج تنظيمات اوليه & نوع يارامترهاى بر رسى شده \\
\hline ل ا ل حمله & 1 1 حمله & تعداد حملات تروريستى انجامشده \\
\hline 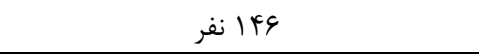 & | l9k ا نفر & تعداد عاملهاى شهروند نابالغ كشته شده \\
\hline 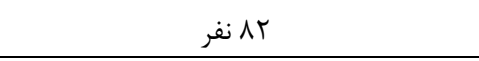 & 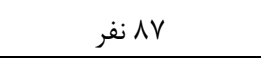 & تعداد عاملهاى شهروند بالغ كشته شده \\
\hline 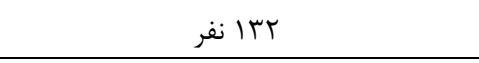 & 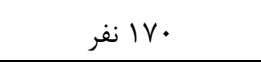 & تعداد عاملهاى شهروند كهنسال كشته شده \\
\hline 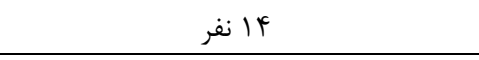 & 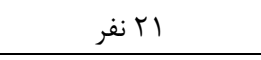 & تعداد عاملهاى دفاعى كشته شده \\
\hline 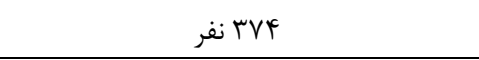 & 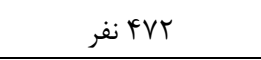 & مجموع عاملهاى كشته شده (شهروند+دفاعى) \\
\hline
\end{tabular}

در تغيير نتايج مدل شبيهسازى دارد. روشهاى زيادى بهمنظور تحليل حساسيت ارائهشده است كه با توجه به ماهيت مسئله مى توانند مورد استفاده قرار گيرند. در اين

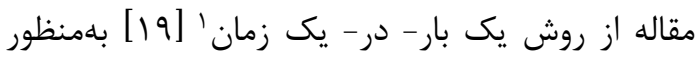
تحليل حساسيت مدل شبيهسازى عامل مبناى حمله يله

$$
\text { • آناليز حساسيّت }
$$

هدف از آناليز حساسيّت بررسى استحكام نتايج مدل با تغيير مقادير يك يا جند پارامتر تشكيل دههنده مدل است

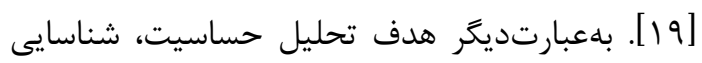
يارامترهايى است كه تغيير در مقادير آنها تأثير زيادى

\section{'One-at-a-time}


تكتى يارامترها براى إرامترهايى كه حساسيت

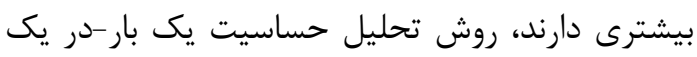

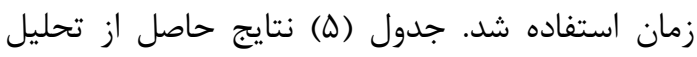
حساسيت مدل به ازاى تغيير دسته مقادير يارامترهاى
تروريستى استفاده شد. به دليل تعداد بالاى يارامترهاى

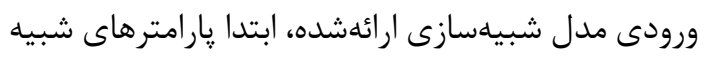
به يكديخر دسته بندى شده و سيس حساسيت دسته يارامترها بهمنظور شناسايى دسته يارامترهاى حساس

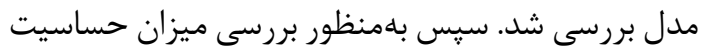
ورودى را نمايش مى لدهد.

جدول ه: تحليل حساسيت يارامترهاى تشكيل دهنده مدل

\begin{tabular}{|c|c|c|c|c|c|c|}
\hline \multirow{2}{*}{ توضيحات } & \multicolumn{2}{|c|}{ كشتهشدَان } & \multicolumn{2}{|c|}{ تروريستى انجامشده حملات } & \multirow{2}{*}{\multicolumn{2}{|c|}{ دسته يارامتر هاى تغيير دادهشده در مدل }} \\
\hline & بله & از & بله & از & & \\
\hline \multirow{3}{*}{ 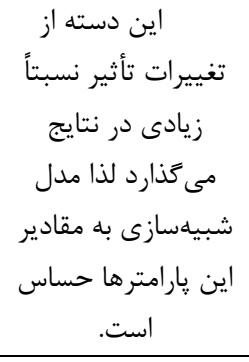 } & \multirow{3}{*}{$\begin{array}{l}\Delta V Y \\
\text { نفر }\end{array}$} & \multirow{3}{*}{$\begin{array}{l}\text { نفر } \\
\text { نفT }\end{array}$} & \multirow[b]{3}{*}{11} & \multirow[b]{3}{*}{$\wedge$} & 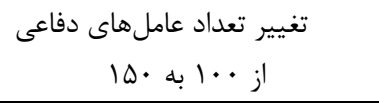 & \multirow{3}{*}{ 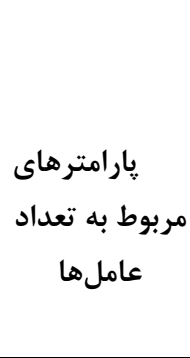 } \\
\hline & & & & & 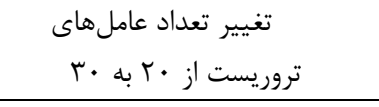 & \\
\hline & & & & & 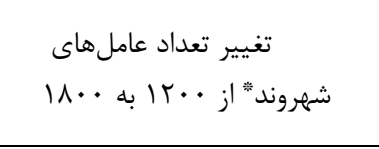 & \\
\hline \multirow{2}{*}{ قبلى تغيير زيادى به حالت } & \multirow{2}{*}{$\begin{array}{l}\Delta T \cdot \text { نفر } \\
\text { ن }\end{array}$} & \multirow{2}{*}{$\begin{array}{l}\text { نVY } \\
\text { نفر }\end{array}$} & \multirow[b]{2}{*}{9} & \multirow[b]{2}{*}{$\wedge$} & 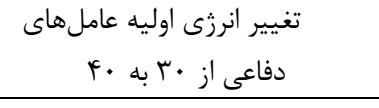 & \multirow{2}{*}{ 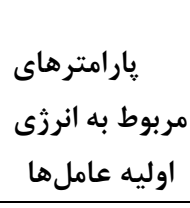 } \\
\hline & & & & & 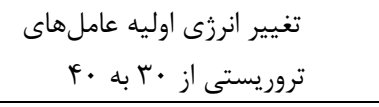 & \\
\hline \multirow{4}{*}{ 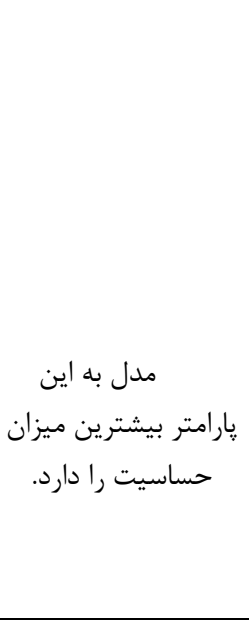 } & \multirow{4}{*}{ صفر } & \multirow{4}{*}{$\begin{array}{l}\text { نفر } \\
\text { نفT }\end{array}$} & \multirow{4}{*}{$\cdot$} & \multirow{4}{*}{$\wedge$} & تروريست لازم جهت انجام حمله تعداد عامله تهاى & \multirow{4}{*}{ 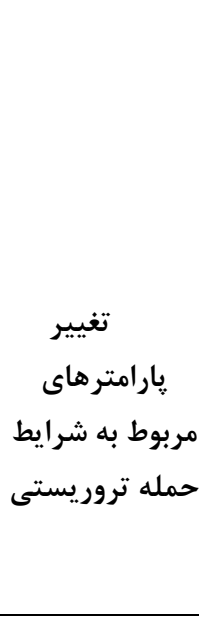 } \\
\hline & & & & & 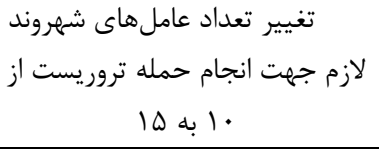 & \\
\hline & & & & & 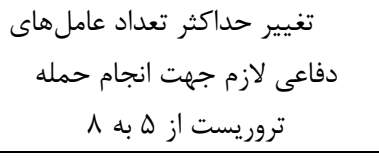 & \\
\hline & & & & & 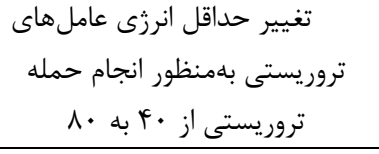 & \\
\hline قبلى تغيير زيادى به حالت & نفر & $\begin{array}{l}\text { نV } \\
\text { نفر }\end{array}$ & $1 \cdot$ & $\wedge$ & \multicolumn{2}{|c|}{ 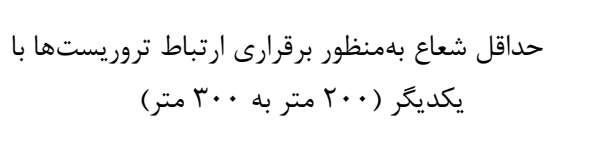 } \\
\hline
\end{tabular}

است كه با افزايش اين يارامترها شرايط براى انجام حمله

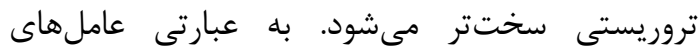
تروريست براى انجام حمله تروريستى ريسك زيادى رادئ
جدول (ه) نشان مىدهد كه مدل، بيشترين حساسيت را، نسبت به يارامترهاى مربوط به شرايط انجام حمله تروريستى دارد. تغيير مقادير اين يارامترها به اين مفهوم 
انجام حمله تروريست، حساسيت بالايى دارد. بطوريكه با

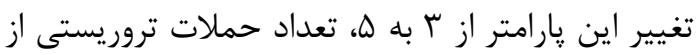

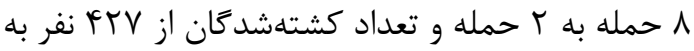
ع ا نفر كاهش مى يابد. همجنين با تغيير مقدار يارامتر مربوط به تعداد عاملهاى تروريست از ب به له ل، تعداد

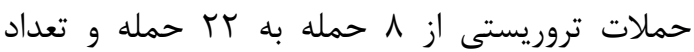

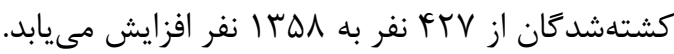

نمىيذيرند. همجنين با كاهش مقادير اين پارامترها

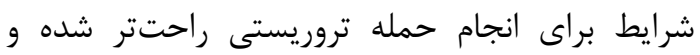

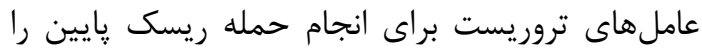
مىيذيرند. جدول (9) نتايج حاصل از تغيير مقدار يارامتر مربوط به تعداد عاملهاى تروريست لازم جهت انجام

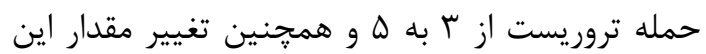

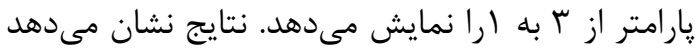

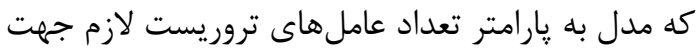

جدول و: نتايج حاصل از تغيير تعداد عاملهاى تروريست لازم جهت انجام حمله تروريست از ؟ به ه و از \ به ا

\begin{tabular}{|c|c|c|c|}
\hline 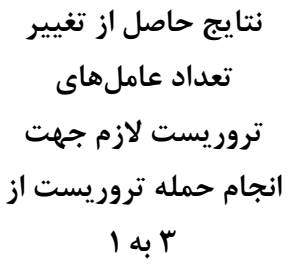 & 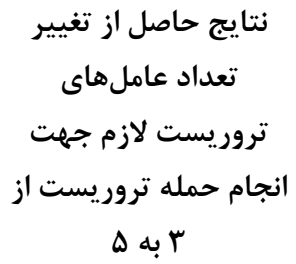 & نتايج تنظيمات اوليه & نوع يارامترهاى بر رسى شده \\
\hline r T Tمله & r l l l & 1 حمله & تعداد حملات تروريستى انجامشده \\
\hline 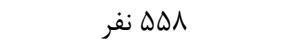 & 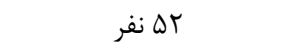 & 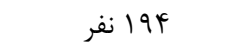 & تعداد عاملهاى شهروند نابالغ كشته شده \\
\hline 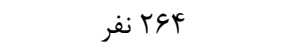 & 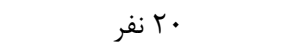 & 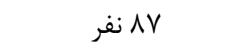 & تعداد عامل هاى شهروند بالغ كشته شده \\
\hline 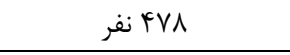 & 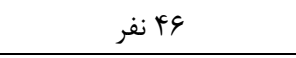 & 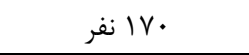 & تعداد عاملهاى شهروند كهنسال كشته شده \\
\hline 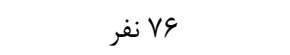 & 人 نفر & آ آنفر & تعداد عاملهاى دفاعى كشته شده \\
\hline 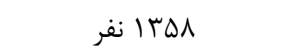 & 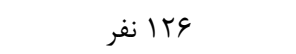 & 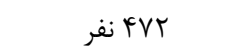 & مجموع عاملهاى كشته شده (شهروند+دفاعى) \\
\hline
\end{tabular}

همجنين تغيير مقدار اين يارامتر از له به ب را نمايش

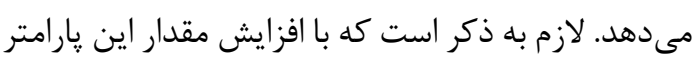
شرايط بيشترى براى انجام حمله تروريستى به وجود

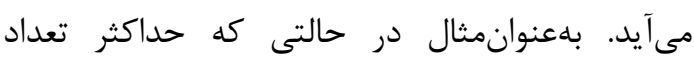

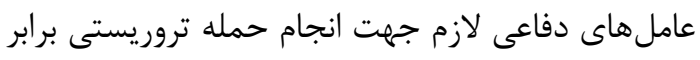
با ها باشد، به اين مفهوم است كه درصورتى كه تعداد عاملهاى دفاعى كمتر از ه باشد امكان حمله تروريستى

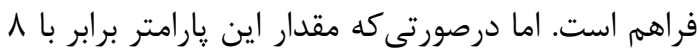
تنظيم شود، درصورتى كه تعداد عامل هاى دفاعى كمتر از ᄉ باشد امكان حمله تروريستى فراهم است لذا شرايط بهترى براى حمله تروريستى فراهم مى شود. نتايج نشان

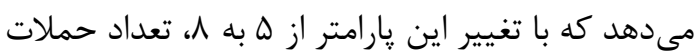

جدول (V) نتايج حاصل از تغيير تعداد عاملهاى شهروند

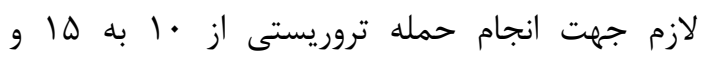

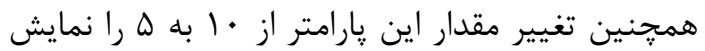

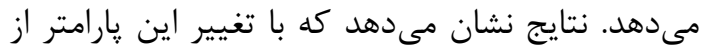

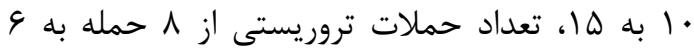

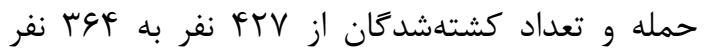
كاهش مى يابد. همجنين با تغيير مقدار يارامتر مربوط به تعداد عاملهاى تروريست از • إ به ه، تعداد حملات

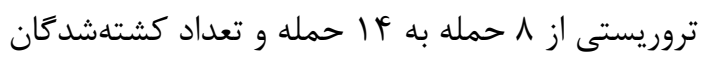

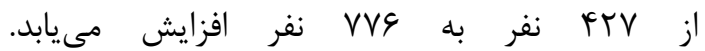

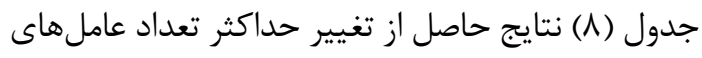

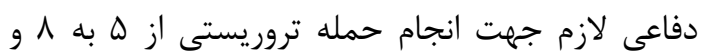




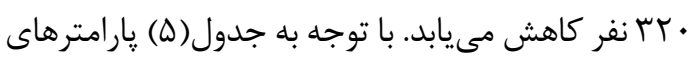

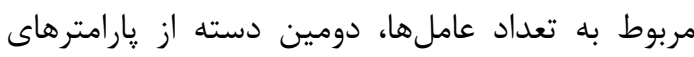
حساس مدل است.
تروريستى از 1 حمله به • • ا حمله و تعداد كشتهشد أنان

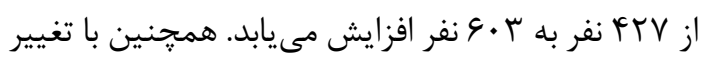

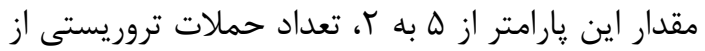

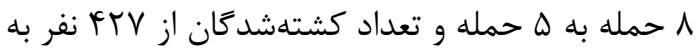

جدول V: نتايج حاصل از تغيير تعداد عامل هاى شهروند لازم جهت انجام حمله تروريستى از •ا به ها و تغيير تعداد

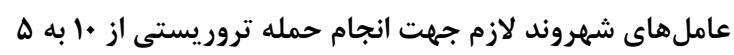

\begin{tabular}{|c|c|c|c|}
\hline تعداد عاملهای تلای شهرو از تغيير & تعداد عاملهاي حاصل از تغهروند & نتايج تنظيمات اوليه & نوع يار امترهاى بررسى شده \\
\hline |f حمله & 9 حمله & 1حمله & تعداد حملات تروريستى انجامشده \\
\hline 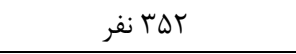 & 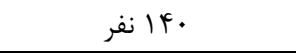 & | l94 ا لفر & تعداد عامل هاى شهروند نابالغ كشته شده \\
\hline 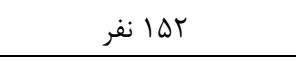 & 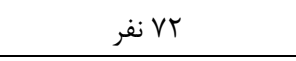 & 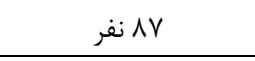 & تعداد عاملهاى شهروند بالغ كشته شده \\
\hline 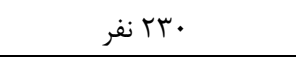 & 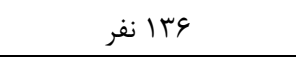 & 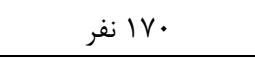 & تعداد عاملهاى شهروند كهنسال كشته شده \\
\hline 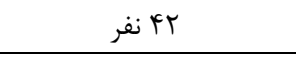 & 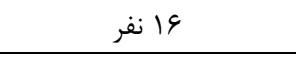 & 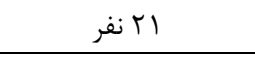 & تعداد عامل هاى دفاعى كشته شده \\
\hline 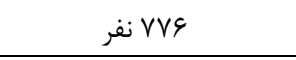 & 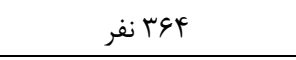 & 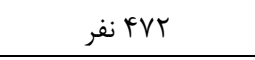 & مجموع عاملهاى كشته شده (شهروند+دفاعى) \\
\hline
\end{tabular}

جدول 1: نتايج حاصل از تغيير حداكثر تعداد عاملهاى دفاعى لازم جهت انجام حمله تروريستى از ها به ^ و تغيير

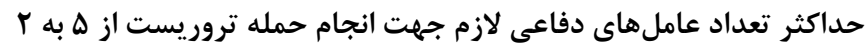

\begin{tabular}{|c|c|c|c|}
\hline 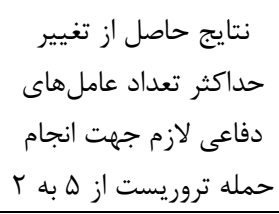 & 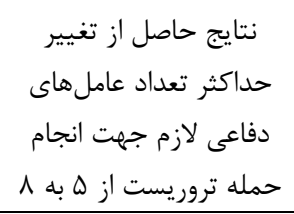 & نتايج تنظيمات اوليه مدل & نوع يارامترهاى بررسى شده \\
\hline ه ه حله & ا 1 حمله & 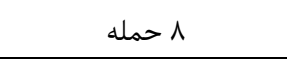 & تعداد حملات تروريستى انجامشده \\
\hline 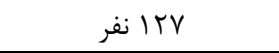 & 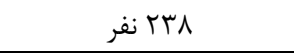 & 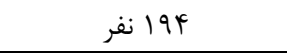 & تعداد عاملهاى شهروند نابالغ كشته شده \\
\hline 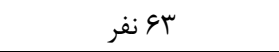 & 1· إنفر & 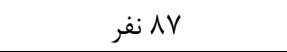 & تعداد عامل هاى شهروند بالغ كشته شده \\
\hline 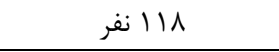 & 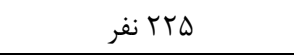 & 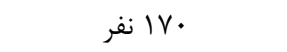 & تعداد عامل هاى شهروند كهنسال كشته شده \\
\hline | آ آنفر & 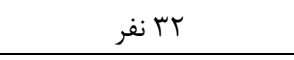 & 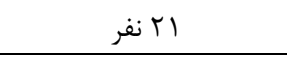 & تعداد عاملهاى دفاعى كشته شده \\
\hline 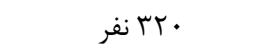 & 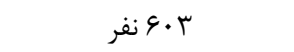 & 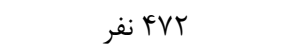 & مجموع عاملهاى كشته شده (شهروند+دفاعى) \\
\hline
\end{tabular}




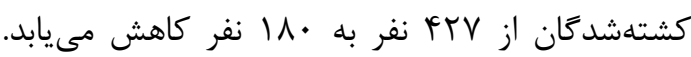

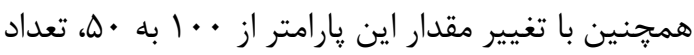

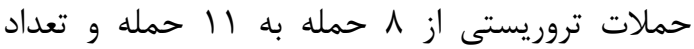

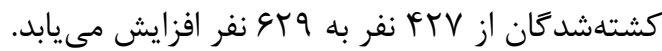

جدول (9) دامنه تغييرات نتايج مدل در صورت تغيير

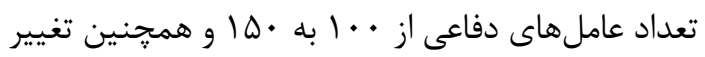

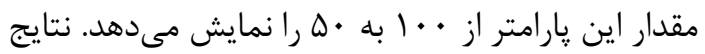

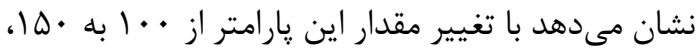

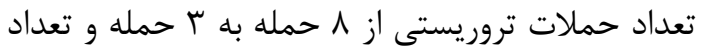

جدول 9: نتايج حاصل از تغيير تعداد عاملهاى دفاعى از ..1 به •ها و نتايج حاصل از تغيير تعداد عاملهاى دفاعى از •.ا به +هـ

\begin{tabular}{|c|c|c|c|}
\hline نتايج حاصل از تغيير تعداد & 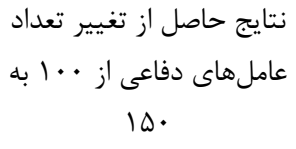 & نتايج تنظيمات اوليه مدل & نوع پارامترهاى بررسى شده \\
\hline 11 11 & 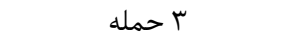 & 1 حمله & تعداد حملات تروريستى انجامشده \\
\hline 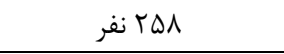 & 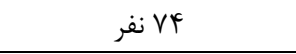 & 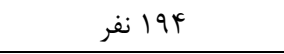 & تعداد عامل هاى شهروند نابالغ كشته شده \\
\hline 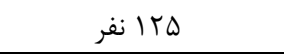 & 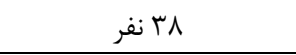 & 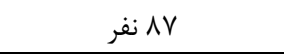 & تعداد عامل هاى شهروند بالغ كشته شده \\
\hline 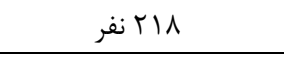 & 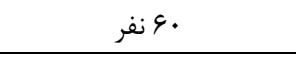 & 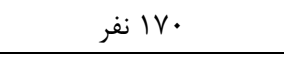 & تعداد عامل هاى شهروند كهنسال كشته شده \\
\hline 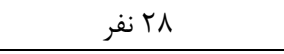 & 1 نفر & ا آنفر & تعداد عاملهاى دفاعى كشته شده \\
\hline 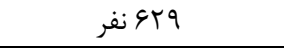 & 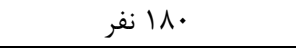 & 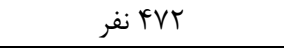 & مجموع عاملهاى كشته شده (شهروند+دفاعى) \\
\hline
\end{tabular}

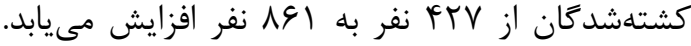

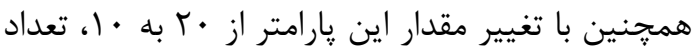

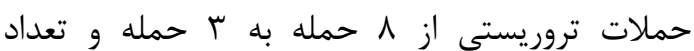

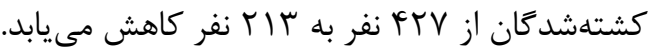

جدول (•) دامنه تغييرات نتايج مدل در صورت تغيير

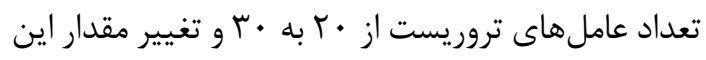

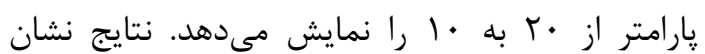

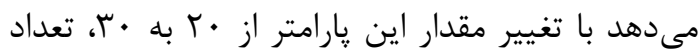

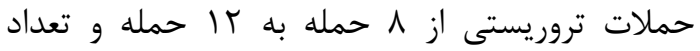

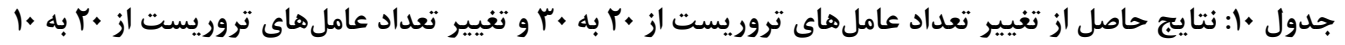

\begin{tabular}{|c|c|c|c|}
\hline تتايج حاصل از تغيير & تتايج حاصل از تغيير & نتايج تنظيمات اوليه & نوع پار امترهاى بر رسى شده \\
\hline r r حمله & r ا حمله & 1 حمله & تعداد حملات تروريستى انجامشده \\
\hline نف VV & 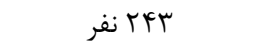 & 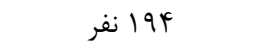 & تعداد عامل هاى شهروند نابالغ كشته شده \\
\hline 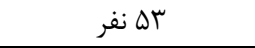 & 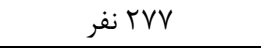 & 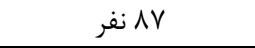 & تعداد عامل هاى شهروند بالغ كشته شده \\
\hline 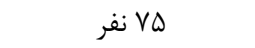 & 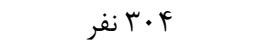 & 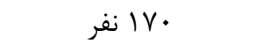 & تعداد عامل هاى شهروند كهنسال كشته شده \\
\hline 1 نفر & 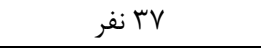 & اب انفر & تعداد عاملهاى دفاعى كشته شده \\
\hline آ اוץ نفر & 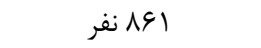 & 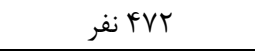 & مجموع عاملهاى كشته شده (شهروند+دفاعى) \\
\hline
\end{tabular}


تعداد حملات تروريستى از 1 حمله به له حمله و تعداد

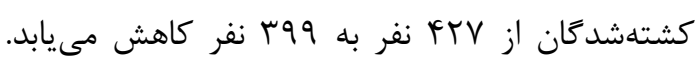

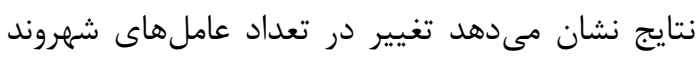

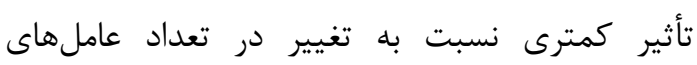

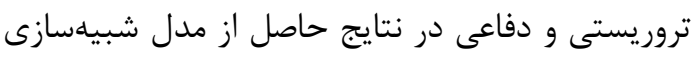

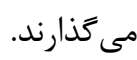

جدول (11) دامنه تغييرات نتايج مدل در صورت تغيير

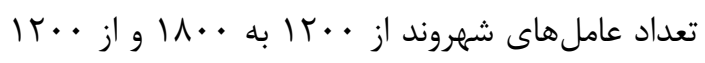

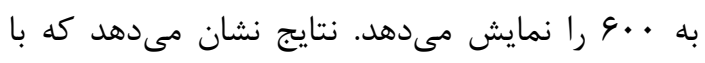

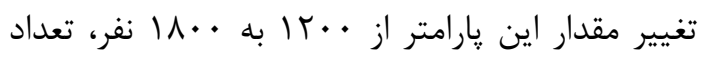

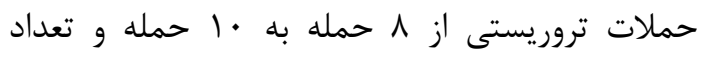

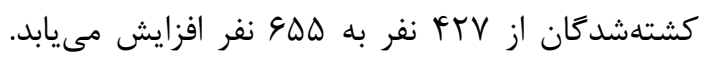

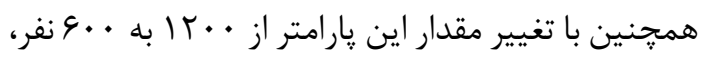

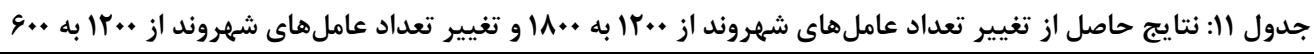

\begin{tabular}{|c|c|c|c|}
\hline تعداد عامل حاصل شاى شهروند & تعداد عامل هائ شاصل از تغيير & نتايج تنظيمات اوليه & نوع يارامترهاى بر رسى شده \\
\hline ه حمله & ا. & 1 حمله & تعداد حملات تروريستى انجامشده \\
\hline 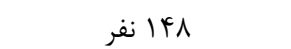 & 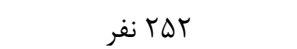 & | & تعداد عاملهاى شهروند نابالغ كشته شده \\
\hline 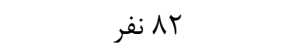 & 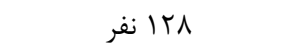 & 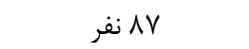 & تعداد عاملهاى شهروند بالغ كشته شده \\
\hline 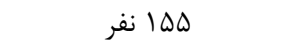 & 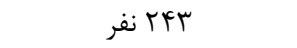 & 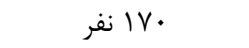 & تعداد عامل هاى شهروند كهنسال كشته شده \\
\hline 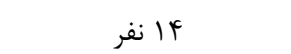 & 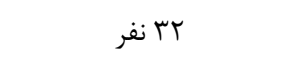 & ا اب نفر & تعداد عاملهاى دفاعى كشته شده \\
\hline 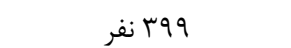 & 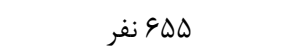 & FVr & مجموع عامل هاى كشته شده (شهروند+دفاعى) \\
\hline
\end{tabular}

مىتواند نتايج مدلسازى را بلهور مستقيم تحت تأثير

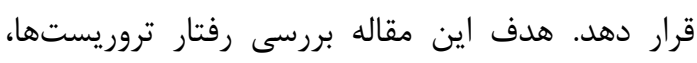

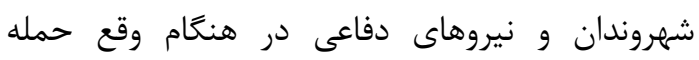

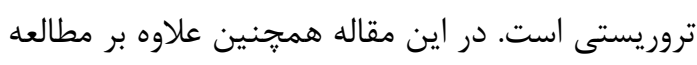

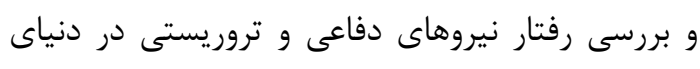

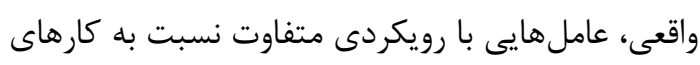

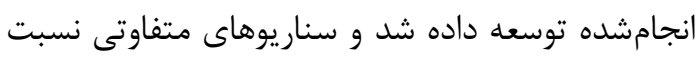

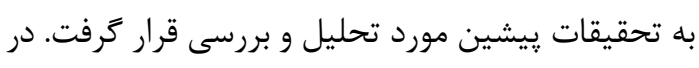

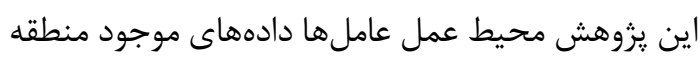
4 شهر تهران شامل شبكه معابر شهرى، مناطق امن و و

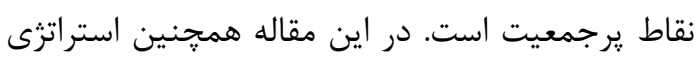

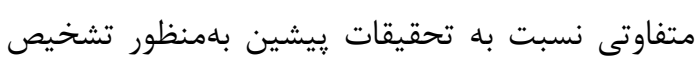

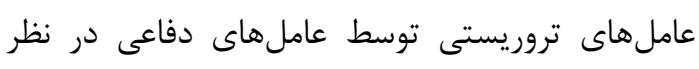

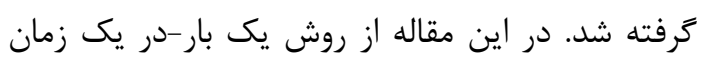
بهمنظور تحليل حساسيت مدل شبيهسازى عامل مبناى
با بررسى تحليل حساسيت مدل در دسته پارامترهاى مربوط به شرايط انجام حمله تروريستى، يارامتر لاتعداد

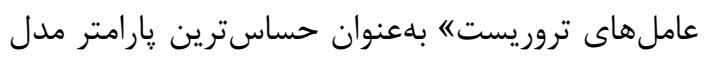

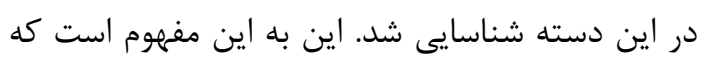

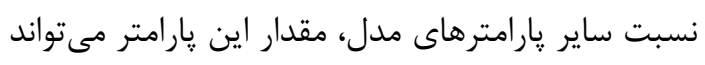

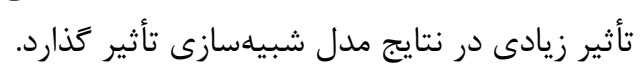

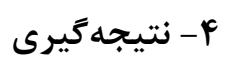

در اين يزوهش مدل عامل مبنايى بهمنظور مدلسازى ندي

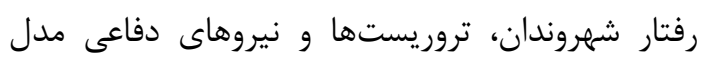

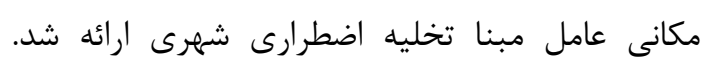

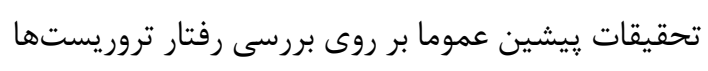

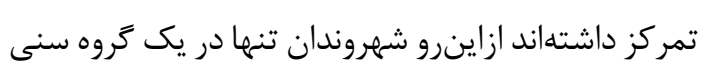

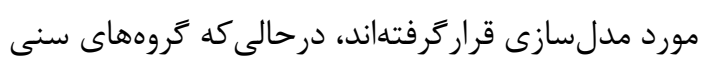

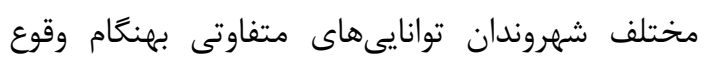

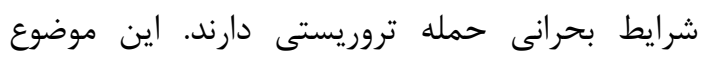


تروريستى صورت گرفته، است. اين موضوع به مديران و كارشناسان كمك مى كند تا بهمنظور به حداقل رساندن ميزان كشتهشدكان تصميمهاى مناسب را اخذ نمايند و از اين طريق باعث افزايش قدرت تصميمزيرى و برنامهريزى مديران شود. باتوجه به نتايج بلهدستآمده از اجراى مدل مكري مكانى عامل مبناى ارائهشده از طريق افزايش تعداد نيروهاى دفاعى در منطقه مى توان احتمال وقوع حمله تروريستى را به عداقل رساند. همجنين در صورت اختصاص دادن درصد نيروهاى دفاعى به حفاظت از نقاط شلوغ و امن و

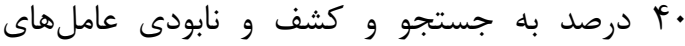
تروريستى در منطقه، تعداد حملات تروريستى و تعداد كشتهشدFان به يكسوم كاهش مى يابد. استفاده از مدلهاى ترافيكى بهصورت آنلاين در مسيريابى عاملها بهعنوان يُشينهاد براى كارهاى بعدى مورد توجه نويسندگان قرار خواهد گرفت.

[1] G. Santos, and B.E. Aguirre, "A critical review of emergency evacuation simulation models", in Proceeding of Conference BuildingOccupant Movement During Fire Emergencies, Gaithersburg, 2004.

[2] V. Karbovskii, D. Voloshin, A. Karsakov, A. Bezgodov and A. Zagarskikh, "Multiscale agent-based simulation in large city areas: emergency evacuation use case", Procedia Computer Science, 51: p. 2367-2376, 2015.

[3] L. Chen, "Agent-based modeling in urban and architectural research: A brief literature review", Frontiers of Architectural Research, 1(2): p. 166-177, 2012

[4] G. Papadimitrioul , B. Sadoun, and C. Papazoglou, "Fundamentals of System Simulation, in Applied System Simulation”, Springer. p. 9-39, 2003.

[5]S. Russell, and P. Norvig, Ai a modern approach. England: Learning, 2(3): p. 4, 2005.

[6] M. Wooldridge, An introduction to multiagent systems. England: John Wiley \& Sons, 2009.
حمله تروريستى استفادهشه است. به دليل تعداد بالاى

يارامترهاى ورودى مدل شبيهسازى ارائهشده، ابتدا يارامترهاى شبيه به يكديخر دستهبندىشده و سيس حساسيت دسته يارامترها بهمنظور شناسايى دسته يارامترهاى حساس مدل بررسى شد. در ادامه بلمنظور

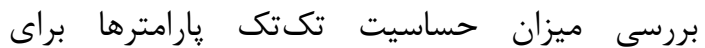
يارامترهايى كه حساسيت بيشترى دارند، روش تحليل حساسيت يك بار - در يك زمان استفاده شد. مدل مكانى عامل مبنا تخليه اضطرارى شهرى قادر خواهد بود كه با بررسى رفتار تروريستها و شهروندان مدان در هنگَام وقوع حمله تروريستى در منطقه شهرى و از طريق بررسى سناريوهاى مختلف، اطلاعات مفيدى ييرامون تلفات ناشى از وقوع حمله تروريستى ارائه دهد. همجنين مدل ارائهشه قادر به ارائه اطلاعاتى پيرامون موقعيتها و نقشه محل وقوع حمله تروريستى و اطلاعاتى ييرامون تعداد كشتهشدگان در هر حمله

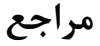

[7]M. Genkin, and A. Gutfraind, "How Do Terrorist Cells Self-Assemble? Insights from an Agent-Based Model”, Social Science Research Network, 2008.

[8] L. Chalmet, R. Francis, and P. Saunders, "Network models for building evacuation" Management science, 28(1): p. 86-105, 1982.

[9] W. Choi, R.L. Francis, H.W. Hamacher, S. Tufekci, "Network models of building evacuation problems with flow-dependent exit capacities", Operational Research, 84: $p$. 1047-1059, 1984.

[10] W. Choi, H.W. Hamacher, and S. Tufekci, "Modeling of building evacuation problems by network flows with side constraints, European Journal of Operational Research, 35(1): p. 98-110, 1988.

[11] G.G. Lovas, "On the importance of building evacuation system components", IEEE Transactions on Engineering Management, 45(2): p. 181-191, 1998.

[12] C. Ren, C. Yang, and S. Jin, "Agent-based modeling and simulation on emergency 
evacuation", Complex Sciences, p.1451-1461, 2009.

[13] P. Mehlitz, N. Rungta, and W. Visser, "A hands-on java pathfinder tutorial”, in Proceedings of the 2013 International Conference on Software Engineering, San Francisco, 2013.

[14] R. Weaver, B. G. Silverman, H. Shin, and R. Dubois, "Modeling and simulating terrorist decision-making: A'Performance Moderator Function'approach to generating virtual opponent", Center for Human Modeling and Simulation, p. 22, 2001

[15] T.H. Ko, and N.M. Berry, "Agent-based modeling with social networks for terrorist recruitment", AAAI, 2004.

[16] K.A. Bertsche, and G. Schwarz, "Agent based simulation of terrorist attacks "protection of potential targets", Cornwallis Group IX: Analysis For Stabilization And Counter-Terrorist Operations, 9: p. 439-456, 2005.

[17] Makarov, V.L. and A.R. Bakhtizin, "Agentbased model for simulation of terrorism in Russia's Caucasus", wcss2010, Germany, 2010.

[18] W.M. Bulleit, and M.W. Drewek, "An agentbased model of terrorist activity”, Proceedings of the North American Association for Computational Social and Organizational Science (NAACSOS 2005), Arizona State, 2005.

[19] A. Saltelli, M. Ratto, T. Andres, F. Campolongo, J. Cariboni, D. Gatelli, M. Saisana, Stefano Tarantola, Global sensitivity analysis: the primer. England:John Wiley \& Sons, 2008.

[20] S.J. Russell, and P. Norvig, Artificial intelligence: a modern approach. Malaysia: Pearson Education Limited, 2016.

[21] S. Tisue, and U. Wilensky, "Netlogo: A simple environment for modeling complexity", International conference on complex systems”, Boston, MA, 2004. 


\title{
Agent-based simulation of emergency evacuation of cities during terrorist attacks
}

\author{
Safa Khazaei ${ }^{1 *}$ \\ 1- Associate professor, Comprehensive University of Imam Hussein
}

\begin{abstract}
In recent years, proper management of resource and timing for emergency evacuation of citizens from the site of terrorist attack has been widely considered by researchers in the field of urban planning. Little studies which have carried out on modeling the behavior of citizens and terrorists in urban environment generally focused on terrorist's behavior. Although different age groups show different abilities in emergencies rised by terrorist attack, in those studies, citizens are modeled in only one group of age. The main purpose of this study is to develope an agent-based model to simulate emergency evacuation due to terrorist attacks considering available infrastructure of a city. In order to evaluate the potential terrorist attack in a city, the behaviour of three groups of agents, including civilians, defense forces, and terrorists, are developed and simulated. In this regard, by examining different scenarios, it is possible to minimize the casualties caused by terrorist attack and rapid evacuation. To perform sensibility analysis and determine the most sensitive parameters, One-at-a-time method is hereby employed. NetLogo software is also used to develop and implement the proposed agent-based model. As a case study, the presented agent-based model has been implemented under various scenarios in district 6 of Tehran and the results have been analyzed. Based on the results of analyzing difference scenarios, it is possible to minimize the possibility of terrorist attack by increasing the number of defense forces. Another useful scenario is to allocate $60 \%$ of the defense forces to protect the busy and safe areas and $40 \%$ to search for and stop terrorist agents in the study area, the number of terrorist attacks and the number of deaths will cut in half.
\end{abstract}

Key words: agent-based modeling and simulation, emeregency evacuation, terrorist attacks.

Correspondence Address. Imam Sadegh site, Comprehensive University of Imam Hussein, Baba'i highway, Lashgarak bridge, Tehran, Iran. Tel: +982177105380.

Email: skhazai@ihu.ac.ir 